\title{
FUNGSIONALISASI HUKUM KEKAYAAN \\ INTELEKTUAL DALAM KOMERSIALISASI \\ KEKAYAAN INTELEKTUAL OLEH INDUSTRI DAN \\ USAHA KECIL MENENGAH DI PULAU LOMBOK NTB
}

\author{
ARI RAHMAD HAKIM B.F ${ }^{\mathbf{1}}$ \\ Fakultas Hukum Universitas Mataram \\ Jl. Majapahit No.62 Mataram \\ Telp (0370) 633035, Fax 626954 \\ Email : - \\ KAHARUDIN ${ }^{2}$ \\ Fakultas Hukum Universitas Mataram \\ J1. Majapahit No.62 Mataram \\ Telp (0370) 633035, Fax 626954 \\ Email : -
}

\begin{abstract}
ABSTRAK
Fungsi hukum dalam komersialisasi dan eksploitasi invensi dan kreasi kekayaan intelektual yang dihasilkan oleh Industri kecil menengah merupakan bagaian dari upaya yang dapat dilakukan agar industri kecil menengah memperoleh kepastian dan perlindungan hukum terhadap penggunaan atau pemanfaatan invensi dan kreasi yang dihasilkannya. Untuk mendapatkan perlindungan hukum agar tidak diklaim dan untuk dapat menuntut pihak lain yang menggunakan tanpa ijin, maka industri kecil menengah yang menghasilkan invensi dan kreasi tertentu sesuai dengan peraturan yang berlaku di bidang kekayaan intelektual di Indonesia maka wajib hukumnya untuk didaftarkan (prinsif konstitutif), kemudian setelah dilakukan pendaftaran Hak Kekayaan Intelektual tersebut dalam pengekploitasian dan pengkomersialisasiannya agar Industri kecil menengah aman, maka dapat dilakukan dengan mekanisme Hukum Jual beli, lisensi (ijin pemanfaatan), Joint venture (usaha patungan) dan melalui mekanisme franchising (waralaba).
\end{abstract}

Kata Kunci : Ekploitasi, komersialisasi, Kekayaan Intelektual, fungsi hukum. 


\section{A. PENDAHULUAN}

Industri dan Usaha Kecil Menengah (IKM) merupakan urat nadi kehidupan ekonomi jutaan rakyat kecil, baik di desa maupun di kota. Oleh karena itu, sektor ini bukan saja sumber mata pencaharian yang menyangkut hajat hidup orang banyak, tetapi juga menyediakan secara luas lapangan kerja bagi mereka yang tidak dan kurang tertidik. Dengan demikian, sektor usaha ini merupakan denyut kehidupan ekonomi rakyat yang mempunyai kedudukan dan peranan yang sangat strategis dalam upaya meningkatkan derajat kemakmuran rakyat kecil, termasuk juga upaya pengentasan masyarakat dari kemiskinan.

Melihat potensi dan peranan yang dimiliki oleh Industri dan Usaha Kecil Menengah ini sehingga pemerintah telah mengeluarkan Undang-Undang Nomor 20 Tahun 2008 tentang Usaha Mikro, Kecil dan Menengah yang selanjutnya dalam tulisan ini disingkat UMKM yang tujuan dikeluarkannya Undang-Undang ini adalah untuk menumbuhkan dan mengembangkan usaha UMKM dalam rangka membangun perekonomian nasional berdasarkan demokrasi ekonomi yang berkeadilan.

Begitu pentingnya peran dan potensi yang dimiliki, maka Industri dan Usaha Kecil Menengah (IKM) sangat beralasan untuk dikembangkan semaksimal mungkin untuk meningkatkan kesejahteraan rakyat sekaligus untuk mendukung pertumbuhan ekonomi daerah. Sehingga kiranya dipandang penting bagi pemerintah (Pusat/Daerah) untuk membantu memenuhi kebutuhan dan fasilitas yang diperlukan oleh Industri dan Usaha Kecil Menengah (IKM) dalam rangka menghadapi tantangan yang cukup berat di era perkembangan teknologi dan persaingan bisnis seperti dalam perdagangan bebas saat ini. Globalisasi telah mendorong terjadinya berbagai perubahan di dalam sektor perdagangan menyebabkan telah terjadinya perdagangan bebas tahun 2010 Asean plus China Free Trade Area.

Dengan demikian tidak dapat dihindari dalam perdagangan bebas ini produk-produk dari Negara-negara ASEAN dan CHINA akan berdatangan ke Indonesia secara bebas dan besar-besaran yang akan berdampak pada dunia usaha dan mengancam perdagangan produk lokal termasuk di Pulau Lombok Nusa Tenggara Barat. Oleh karena itu pemerintah harus menyiapkan industri dan Usaha Kecil Mengah dengan meningkatkan daya saing produk yang berkualitas, menciptakan kondisi agar orang lokal tetap mencintai dan menggunkan produk lokal serta memberikan jaminan pelindungan hukum terhadap invensi atau kreasi yang dihasilkan oleh para industri dan usaha kecil menengah (IKM) melalui mekanisme dan memfungsikan hukum hak kekayaan intelektual dalam rangka melindungi dan memberikan kepastian hukum bagi Industri dan Usaha Kecil Menengah, baik dalam kegiatan penemuan kekayaan intelektual, pelindungan terhadap produk yang dihasilkan, demikian juga terhadap kegiatan eksploitasi dan kemersialisasi kekayaan intelektual yang dimiliki.

\section{B. PEMBAHASAN}

\section{Fungsi Hukum Hak Kekayaan Intelektual Terhadap Invensi yang dihasilkan oleh Industri dan Usaha Kecil Menengah}

Hak Kekayaan Intelektual merupakan hak yang berasal dari karya, karsa dan daya cipta kemampuan intelektualitas manusia yang memiliki manfaat serta berguna dalam menunjang kehidupan manusia dan menpunyai nilai ekonomi. Bentuk nyata dari hasil karya, karsa dan daya cipta intelektualitas manusia tersebut dapat berupa ilmu pengetahuan, teknologi, seni dan sastra. Inovasi (penemuan) atau hasil kreasi dari suatu pekerjaan dengan memakai kemampuan intelektual adalah wajar bila penemu atau pencipta memperoleh imbalan. Imbalan tersebut 
dapat berupa kekayaan intelektual dengan menggunakan instrument-instrumen hukum yang ada, yakni hak Cipta, Paten, Merek dan Indikasi Geografis, Rahasia Dagang, Desain Industri, Desain Tata Letak Sirkuit Terpadu dan perlindungan Varitas Tanaman.

Beberapa alasan mengapa Hak Kekayaan Intelektual harus dilindungi diantaranya yaitu karena hak yang diberikan kepada seorang pencipta (dibidang ilmu pengetahuan, seni dan sastra ataupun inventor dibidang teknologi baru yang mengandung langkah inventif, merupakan wujud dari pemberian penghargaan dan pengakuan atas keberhasilan manusia dalam melahirkan karya-karya inovatifnya. Konsekwensi hukumnya maka kepada penemu dan pencipta tersebut harus diberikan perlindungan hukum untuk mendapatkan kepastian dalam penggunaan dan pemanfaatan hak, melarang orang lain menggunakan tanpa ijin serta untuk menuntut pihak lain yang menggunakan hak tersebut tanpa ijin kreator dan inventornya. Kepada mereka yang telah menuangkan kreativitas dan telah menemukan suatu invensi dengan mengerahkan segala kemampuan yang dimiliki itu seharusnya Negara memberikan hak eksklusif untuk mengekploitasi Hak Kekayaan Intelektual tersebut dengan aman sebagai imbalan atas jerih payahnya tersebut.

Dengan demikian, maka Negara sebagai institusi yang berwenang dan mempunyai kewajiban untuk memberikan perlindungan hukum serta mendistribusikan keadilan bagi warga negaranya serta hendaknya dapat memberikan regulasi melalui fungsi hukum yang ada. Hukum ${ }^{1}$ merupakan suatu kebutuhan yang melekat pada

${ }^{1}$ Satjipto Rahardjo, Hukum Dalam Perspektif Sejarah dan Perubahan Sosial dalam Pembangunan Hukum Dalam Perspektif Hukum Nasional, Rajawali Press, Jakarta, 1996, hal.19 kehidupan sosial dalam suatu masyarakat, yaitu bahwa hukum akan melayani anggota-anggota masyarakat, baik berupa pengalokasian kekuasaan, pendistribusian sumber-sumber daya serta melindungi kepentingan anggota masyarakat itu sendiri oleh karenanya hukum menjadi semakin penting peranannya sebagai sarana untuk mewujudkan kebijaksanaan-kebijaksanaan pemerintah. Kesadaran yang menyebabkan bahwa hukum merupakan instrument penting untuk mewujudkan tujuan-tujuan tertentu, menjadikan hukum sebagai sarana yang secara sadar dan aktif digunkan untuk mengatur masyarakat, melalui penggunaan peraturan hukum yang dibuat dengan sengaja.

Pemberlakuan hukum adalah sebagai sarana untuk mencapai tujuan sebagaimana yang diharapkan, secara teknis hukum dapat memberikan hal-hal sebagai berikut: ${ }^{2}$

a. Hukum merupakan suatu sarana untuk menjamin kepastian dan memberikan prediktabilitas di dalam kehidupan masyarakat;

b. Hukum merupakan sarana pemerintah untuk menetapkan sanksi;

c. Hukum sering dipakai oleh pemerintah sebagai sarana untuk melindungi melawan kritik;

d. Hukum dapat digunakan sebagai sarana untuk mendistribusikan sumber-sumber daya.

Hukum sebagai sarana pembangunan dapat mengabdi dalam tiga sektor, yaitu $:^{3}$

a. Hukum sebagai alat tertib (ondering) yang berarti hukum menciptakan suatu kerangka bagi pengambilan keputusan politik dan pemecahan perselisihan yang mungkin timbul melalui suatu hukum acara yang baik;

b. Hukum sebagai alat penjaga

\footnotetext{
${ }^{2}$ Ibid, hal. 20

${ }^{3}$ Mardjono Reksodiputro, Sistem Peradilan Pidana Indonesia (melihat Kejahatan dan Penegakan Hukum dalam Batas-Batas Toleransi). Pusat Keadilan dan Pengabdian Hukum, Jakarta, 1994, hal. 76
} 
keseimbangan (balancing) yang berarti hukum berfungsi untuk menjaga keseimbangan dan harmonisasi antara kepentingan umum dan kepentingan pribadi;

c. Hukum sebagai katalisator yang berarti hukum berfungsi untuk memudahkan terjadinya proses perubahan melalui pembaharuan hukum dengan bantuan tenaga kreatif dibidang profesi hukum.

Hukum merupakan suatu kebutuhan yang melekat pada kehidupan sosial itu sendiri, yaitu hukum akan melayani kebutuhan anggota-anggota masyarakat, baik berupa pengalokasian kekuasaan, pendistribusian sumber daya - sumber daya serta melindungi kepentingan anggota masyarakat itu sendiri. Oleh karena itu hukum semakin dirasakan penting peranannya sebagai sarana untuk mewujudkan kebijaksanaan-kebijaksanaan pemerinntah. Hukum mempunyai arti penting bagi kekuasaan formal lembagalembaga Negara, unit-unit pemerintah, dan pejabat Negara dan pemerintah. Legalisasi kekuasaan itu dilakukan melalui penetapan landasan hukum bagi kekuasaan melalui aturan hukum. Di samping itu hukum dapat pula berperan mengontrol kekuasaan sehingga pelaksanaannya dapat dipertanggung jawabkan secara legal dan etis.

Perubahan hukum dalam masyarakat yang sedang berubah meliputi perubahan hukum tidak tertulis, perubahan di dalam menafsirkan hukum perundangundangan, perubahan konsepsi mengenai hak milik umpamanyadalam masyarakat industri modern, perubahan pembatasan hak milik yang bersifat publik, perubahan fungsi dari perjanjian kontrak, peralihan tanggung jawab dari tuntutan ganti rugi ke ansuransi, perubahan dalam jangkauan ruang lingkup hukum internasional dan perubahan-perubahan lain.

Setiap sistem hukum menunjukkan empat unsur dasar, yaitu: pranata peraturan, proses penyelenggaraan hukum, prosedur pemberian keputusan oleh pengadilan dan lembaga penegakan hukum. Dalam hal ini pendekatan pengembangan terhadap sistem hukum menekankan pada beberapa hal, yaitu: bertambah meningkatnya diferensiasi internal dari keempat unsur-dasar system hukum tersebut, menyangkut perangkat peraturan, penerapan peraturan, pengadilan dan penegakan hukum serta pengaruh diferensiasi lembaga dalam masyarakat terhadap unsur-unsur dasar tersebut. ${ }^{4}$

Perkembangan hukum difokuskan pada hubungan timbal balik antara diferensiasi hukum dengan diferensiasi sosial yang dimungkinkan untuk menggarap kembali peraturan-peraturan, kemampuan untuk membentuk hukum, keadilan dan institusi penegak hukum. Diferensiasi itu sendiri merupakan ciri yang melekat pada masyarakat yang tengah mengalami perkembangan. Melalui diferensiasi ini suatu masyarakat terurai ke dalam bidang spesialisasi yang masing-masing sedikit banyak mendapatkan kedudukan yang otonom.

Perkembangan demịkian ini menyebabkan susunan masyarakat menjadi semakin komplek. Dengan diferensiasi dimungkinkan untuk menimbulkan daya adaptasi masyarakat yang lebih besar terhadap lingkungannya. Sebagai salah satu subsistem dalam masyarakat, hukum tidak terlepas dari perubahan-perubahan yang terjadi masyarakat. Hukum disamping mempunyai kepentingan sendiri untuk mewujudkan nilai-nilai tertentu di dalam masyarakat terikat pada bahan-bahan yang disediakan oleh masyarakatnya. Dengan demikian dapat dikatakan bahwa hukum sangat dipengaruhi oleh perubahan yang terjadi di sekelilingnya.

Untuk melihat hubungan antara hukum dan perubahan sosial perlu sebuah

\footnotetext{
${ }^{4}$ Ibid, hal. 79
} 
alat dalam bentuk konsep yang menjelaskan secara fungsional tempat hukum dalam masyarakat. Alat tersebut menunjukkan pekerjaan hukum yaitu: (1) Merumuskan hubungan antara anggota masyarakat dengan menentukan perbuatan yang dilarang dan yang boleh dilakukan; (2) Mengalokasikan dan menegaskan siapa yang boleh menggunakan kekuasaan, atas siapa dan bagaimana prosedurnya; (3) Mempertahankan kemampuan adaptasi masyarakat dengan cara mengatur kembali hubungan-hubungan dalam masyarakat manakala terjadi perubahan. ${ }^{5}$

Apabila hukum itu dipakai dalam arti suatu bentuk karya manusia tertentu dalam rangka mengatur kehidupannya, maka dapat dijumpai dalam berbagai lambang. Diantara lambang tersebut yang paling tegas dan terperinci mengutarakan isinya adalah bentuk tertulis atau dalam lebih sering dikenal dengan bentuk sistem hukum formal. Segi yang menandai bentuk yang demikian adalah terdapatnya kepastian dalam normanormanya dan segi yang lainnya adalah kekakuan. Kepastian hukum memang banyak disebabkan karena sifat kekakuan bentuk pengaturan ini dan gilirannya menyebabkan timbulnya keadaan yang lain lagi seperti kesenjangan diantara keadaan-keadaan, hubungan-hubungan serta peristiwaperistiwa dalam masyarakat yang diatur oleh hukum formal tersebut.

Tuntutan terhadap terjadinya perubahan hukum, mulai timbul manakala kesenjangan tersebut telah mencapai tingkat sedemikian rupa, sehingga kebutuhan akan perubahan semakin mendesak. Tingkat yang demikian itu bisa ditandai oleh tingkah laku anggota masyarakat yang tidak lagi merasakan kewajiban yang dituntut oleh hukum sebagai sesuatu yang harus dijalankan. Sehingga terdapat suatu jurang yang

\footnotetext{
${ }^{5}$ Ibid, hal 79
}

memisahkan antara tanggapan hukum di satu pihak dan masyarakatnya, dilain pihak mengenai perbuatan yang seharusnya dilakukan. Perubahan hukum formal, dapat dilihat dari segi yang berhubungan dengan fungsi-fungsi yang dijalankan oleh hukum, menyangkut pengertian hukum sebagai sarana pengintegrasian, yang kemudian lebih dijabarkan lagi ke dalam fungsinya yang berlainan seperti fungsi kontrol sosial. Dengan terjadinya perubahan-perubahan, hukum harus menjalankan usahanya sedemikian rupa sehingga konflik-konflik serta kepincangan-kepincangan yang mungkin timbul tidak menganggu ketertiban serta produktivitas masyarakat.

Salah satu kekayaan yang bernilai tinggi yang dimiliki oleh setiap manusia yang diwujudkan dalam berbagai bentuk kreasi, invensi dan inovasi apa yang dinamakan kekayaan intelektual. Secara substantive pengertian hak kekayaan intelektual dapat dideskripsikan sebagai hak atas kekayaan yang timbul atau lahir karena kemampuan intelektual manusia.

Penggambaran di atas pada dasarnya memberikan kejelasan bahwa produktivitas manusia dibidang intelektual ditunjukkan dengan seberapa besar Kekayaan Intelektual yang dihasilkan oleh manusia yang memang menjadikan karya-karya yang timbul atau lahir karena kemampuan intelektual manusia sebagai inti dan obyek pengaturannya. Karya-karya intelektual tersebut apakah dibidang ilmu pengetahuan atau seni, sastra atau teknologi, dilahirkan dengan pengorbanan yang tidak sedikit memakan waktu dan biaya menjadikan karya yang dihasilkan menjadi bernilai tinggi. Apalagi dengan manfaat ekonomi yang dapat dinikmati, maka nilai ekonomi yang melekat menumbuhkan konsep kekayaan (property) terhadap karya-karya intelektual itu bagi dunia usaha terlebih lagi bagi industry dan usaha kecil menengah, karya-karya tersebut dijadikan sebagai asset dalam berusaha atau 
perusahaan.

Berdasarkan hasil penelitian di Dinas Perindustrian dan Perdagangan Propinsi Nusa Tenggara Barat, ${ }^{6}$ bahwa dari data yang dimiliki setidaknya ada 144 pelaku usaha yang terdaftar di Kantor Dinas Perdagangan Propinsi Nusa Tenggara Barat yang terdiri dari pelaku usaha atau Industri Kecil, Pelaku Usaha Menengah dan sedikit Pelaku Usaha dengan kategori Besar. Dari 144 pelaku usaha tersebut hampir 95 persen tergolong Industry dan Pelaku Usaha Kecil Menengah yang ratarata mempunyai kekayaan intelektual seperti Merek, Desain Industri dan Hak Cipta yang perlu mendapat perhatian melalui fungsi hukum hak kekayaan intelektual sesuai dengan hukum positif yang berlaku. Di bawah ini ditampilkan rekapitulasi pendaftaran Merek yang dilakukan oleh Industri dan Usaha Kecil Menengah difasilitasi oleh Kantor Dinas Perindustrian Propinsi Nusa Tenggara Barat Tahun 2016.

\begin{tabular}{|c|c|c|c|c|}
\hline $\begin{array}{l}\mathbf{N} \\
\mathbf{0}\end{array}$ & NAMA & ALAMAT & $\begin{array}{c}\text { JENIS } \\
\text { PROD } \\
\text { UK }\end{array}$ & MEREK \\
\hline 1 & $\begin{array}{l}\text { Komala } \\
\text { Apryana }\end{array}$ & $\begin{array}{l}\text { Jl. Kemuning } \\
\text { No. } 2 \\
\text { Gomong Kota } \\
\text { Mataram }\end{array}$ & $\begin{array}{l}\text { Stik } \\
\text { Ubi- } \\
\text { Ubian, } \\
\text { Kentan } \\
\text { g }\end{array}$ & Mitutu's \\
\hline 2 & $\begin{array}{l}\text { L. Arman } \\
\text { Sobri, ST }\end{array}$ & $\begin{array}{l}\text { Perum Taman } \\
\text { Alamanda } \\
\text { Blok C No. } 08 \\
\text { Kel. Karang } \\
\text { Pule kec. } \\
\text { Sekarbela } \\
\text { Kota } \\
\text { MaTaram }\end{array}$ & $\begin{array}{l}\text { Kerajin } \\
\text { an } \\
\text { lampu } \\
\text { tidur } \\
\text { dari } \\
\text { benang }\end{array}$ & AR SOB \\
\hline 3 & $\begin{array}{l}\text { Muhammad } \\
\text { Nashif }\end{array}$ & $\begin{array}{l}\text { Jl. Adi } \\
\text { Sucipto Gang } \\
\text { Perjuangan } \\
\text { No. } 19 \\
\text { lingkungan } \\
\text { Batu Raja kec. } \\
\text { Ampenan } \\
\text { Kota. } \\
\text { Mataram } \\
\end{array}$ & $\begin{array}{l}\text { Restaur } \\
\text { ant \& } \\
\text { Caterin } \\
\mathrm{g}\end{array}$ & Gizi Food \\
\hline 4 & $\begin{array}{l}\text { Sri } \\
\text { Prihatiwin }\end{array}$ & $\begin{array}{l}\text { Jl. Libro No. } \\
\text { 05 ampenan } \\
\text { Kota Mataram }\end{array}$ & Kaos & Gilagili \\
\hline 5 & $\begin{array}{l}\text { Bq. Yeni } \\
\text { Oktavianti }\end{array}$ & $\begin{array}{l}\text { Jl. R.A Kartini } \\
\text { No. } 105 \\
\text { Monjok Baru . }\end{array}$ & $\begin{array}{l}\text { Kue } \\
\text { kering } \\
\text { dan kue }\end{array}$ & $\begin{array}{l}\text { Labay } \\
\text { Baru }\end{array}$ \\
\hline
\end{tabular}

${ }^{6}$ Hasil Wawancara dengan Raditya Pratama, Staff Dinas Perindag Propinsi Nusa Tenggara Barat, tanggal 9 September 2017

\begin{tabular}{|c|c|c|c|c|}
\hline & & $\begin{array}{l}\text { Kel. Monjok } \\
\text { Timur Kota } \\
\text { Mataram }\end{array}$ & basah & \\
\hline 6 & $\begin{array}{l}\text { Irawan } \\
\text { Aprianto }\end{array}$ & $\begin{array}{l}\text { Jl. Ali Napiah } \\
\text { no. } 2 \text { kel. } \\
\text { Babakan kec. } \\
\text { Sandubaya } \\
\text { kota mataram }\end{array}$ & $\begin{array}{l}\text { Mesin } \\
\text { Pertani } \\
\text { an }\end{array}$ & $\begin{array}{l}\text { Roda } \\
\text { Teknik }\end{array}$ \\
\hline 7 & $\begin{array}{l}\text { Saeful } \\
\text { Muslim, M } \\
\text { Pd }\end{array}$ & $\begin{array}{l}\text { Jl. TGH. } \\
\text { Abdul Karim } \\
\text { RT. } 11 \\
\text { Karang } \\
\text { Kuripan Barat } \\
\text { Desa Kediri } \\
\text { Kab. Lombok } \\
\text { Barat }\end{array}$ & $\begin{array}{l}\text { Pendidi } \\
\text { kan }\end{array}$ & $\begin{array}{l}\text { SMPIT } \\
\text { Tunas } \\
\text { Cendekia } \\
\text { Mataram }\end{array}$ \\
\hline 8 & $\begin{array}{l}\text { Ahmad } \\
\text { Zaki, SE }\end{array}$ & $\begin{array}{l}\text { Dusun Karang } \\
\text { Bedil Selatan } \\
\text { Rt 03 Jl. TGH. } \\
\text { Abdul Hafidz } \\
\text { NO. 14 Kediri } \\
\text { Kab. Lombok } \\
\text { Barat NTB } \\
83362\end{array}$ & $\begin{array}{l}\text { Pakaia } \\
\text { n Alas } \\
\text { Kaki } \\
\text { dan } \\
\text { Tutup } \\
\text { Kepala }\end{array}$ & Alif Bata \\
\hline 9 & $\begin{array}{l}\text { Zainul } \\
\text { Mukhlis }\end{array}$ & $\begin{array}{l}\text { Dususn Suka } \\
\text { Damai Desa } \\
\text { Santong Kec. } \\
\text { Kayangan } \\
\text { Kab. Lombok } \\
\text { Utara }\end{array}$ & AMDK & $\begin{array}{l}\text { Santong } \\
\text { Spring }\end{array}$ \\
\hline 10 & $\begin{array}{l}\text { M. Roby } \\
\text { Satriawan }\end{array}$ & $\begin{array}{l}\text { Jl. Cempaka } \\
\text { No. } 2 \text { Kel. } \\
\text { Prapen Kec. } \\
\text { Praya Kab. } \\
\text { Lombok } \\
\text { Tengah NTB }\end{array}$ & $\begin{array}{l}\text { Kaos } \\
\text { Oblong } \\
\text { / T- } \\
\text { Shirt } \\
\text { dan } \\
\text { Souven } \\
\text { ir } \\
\end{array}$ & Lepank Ijo \\
\hline 11 & M. Maliki & $\begin{array}{l}\text { RW. Adil } \\
\text { Desa } \\
\text { Pringgasela } \\
\text { Kec. } \\
\text { Pringgasela } \\
\text { Kab.Lombok } \\
\text { Timur NTB }\end{array}$ & $\begin{array}{l}\text { Kain } \\
\text { Tenun }\end{array}$ & $\begin{array}{l}\text { Tarung } \\
\text { Berjaya }\end{array}$ \\
\hline 12 & $\begin{array}{l}\text { Irawan } \\
\text { Efendi }\end{array}$ & $\begin{array}{l}\text { Lingkungan } \\
\text { Gandor RT } 30 \\
\text { Kel. Selong } \\
\text { Kec. Selong } \\
\text { Kecamatan } \\
\text { Selong Kab. } \\
\text { Lombok } \\
\text { Timur } \\
\end{array}$ & $\begin{array}{l}\text { Keripik } \\
\text { Talas }\end{array}$ & Loh Mak? \\
\hline 13 & $\begin{array}{l}\text { Hj. Siti } \\
\text { Aisyah }\end{array}$ & $\begin{array}{l}\text { BTN Karang } \\
\text { Dima Blok C } \\
\text { No. 1 Rt } \\
001 / 004 \\
\text { Kecamatan } \\
\text { Labuhan } \\
\text { Badas } \\
\text { Kabupaten } \\
\text { Subawa NTB } \\
84351 \\
\end{array}$ & $\begin{array}{l}\text { Kue } \\
\text { Basah } \\
\text { dan } \\
\text { Kue } \\
\text { Kering }\end{array}$ & Narisa \\
\hline 14 & $\begin{array}{l}\text { Arie } \\
\text { Priyono }\end{array}$ & $\begin{array}{l}\text { Jl. Mameru } \\
\text { Bata No. } 25 \\
\text { Potu Kab. } \\
\text { Dompu NTB } \\
84214\end{array}$ & $\begin{array}{l}\text { Minum } \\
\text { an } \\
\text { dengan } \\
\text { bahan } \\
\text { dasar } \\
\text { kopi }\end{array}$ & Vanbredo \\
\hline
\end{tabular}




\begin{tabular}{|c|c|c|c|c|}
\hline 15 & $\begin{array}{l}\text { Arie } \\
\text { Priyono }\end{array}$ & $\begin{array}{l}\text { Jl. Mameru } \\
\text { Bata No. } 25 \\
\text { Potu Kab. } \\
\text { Dompu NTB } \\
84214\end{array}$ & $\begin{array}{l}\text { Abon } \\
\text { Ikan, } \\
\text { Nugget } \\
\text { Ikan }\end{array}$ & D' Amie \\
\hline 16 & $\begin{array}{l}\text { Arief } \\
\text { Budiman }\end{array}$ & $\begin{array}{l}\text { Kelurahan } \\
\text { Penaraga Rt. } \\
09 \text { Rw 03 } \\
\text { Kec. Raba } \\
\text { Kota Bima }\end{array}$ & Garam & $\begin{array}{l}\text { Budi } \\
\text { Samudera }\end{array}$ \\
\hline 17 & $\begin{array}{l}\text { KUSUMA } \\
\text { WATI }\end{array}$ & $\begin{array}{l}\text { Jl. Lestari } \\
\text { Gang Umar } \\
\text { No. 06 } \\
\text { Moncok } \\
\text { Telaga Mas } \\
\text { Pejarakan } \\
\text { Karya } \\
\text { Ampenan } \\
\text { Kota Mataram }\end{array}$ & Bumbu & $\begin{array}{l}\text { MAIQ } \\
\text { MANGET }\end{array}$ \\
\hline 18 & ISNAINI & $\begin{array}{l}\text { Jl. Gunung } \\
\text { Lawu II No. } \\
312 \\
\text { Lingkungan } \\
\text { Pelita Dasan } \\
\text { Agung Baru } \\
\text { Selaparang } \\
\text { Kota Mataram }\end{array}$ & Dodol & $\begin{array}{l}\text { KENYAL } \\
\text { KENYIL }\end{array}$ \\
\hline 19 & $\begin{array}{l}\text { TETET } \\
\text { SARIHEM } \\
\text { AWATI }\end{array}$ & $\begin{array}{l}\text { Jln. } \\
\text { Batubolong II } \\
\text { NO. 07 Griya } \\
\text { Pagutan Indah } \\
\text { Kota Mataram }\end{array}$ & Sandal & Keingesne \\
\hline 20 & $\begin{array}{l}\text { NOVARID } \\
\text { A RETNO } \\
\text { N.S }\end{array}$ & $\begin{array}{l}\text { Jl. Jend. } \\
\text { Sudirman } \\
\text { Villa Palm B } \\
\text { 10 Rembiga } \\
\text { Kota Mataram }\end{array}$ & Kripik & Nafal's \\
\hline 21 & $\begin{array}{l}\text { SRI } \\
\text { SUHERNI }\end{array}$ & $\begin{array}{l}\text { Kr. Kemong } \\
\text { Cakranegara } \\
\text { Barat RT } \\
\text { 005/RW } 116 \\
\text { Cakranegara } \\
\text { Kota Mataram }\end{array}$ & Kripik & D'hers \\
\hline 22 & $\begin{array}{l}\text { Ir. H. } \\
\text { ISMAIL, } \\
\text { Msi }\end{array}$ & $\begin{array}{l}\text { Jl. Arwana } \\
\text { No. } 1 \text { BTN } \\
\text { Taman } \\
\text { Mutiara } \\
\text { Lingkungan } \\
\text { Pesongoran } \\
\text { Rt. 007 Rw. } \\
\text { 095 Kelurahan } \\
\text { Pagutan Barat, } \\
\text { Mataram }\end{array}$ & $\begin{array}{l}\text { Sari } \\
\text { Ikan } \\
\text { Gabus, } \\
\text { Abon } \\
\text { Ikan } \\
\text { Gabus }\end{array}$ & $\begin{array}{l}\text { ANTA } \\
\text { MAIQ }\end{array}$ \\
\hline 23 & $\begin{array}{l}\text { Saeful } \\
\text { Muslim, M } \\
\text { Pd }\end{array}$ & $\begin{array}{l}\text { Jl. TGH. } \\
\text { Abdul Karim } \\
\text { RT. } 11 \\
\text { Karang } \\
\text { Kuripan Barat } \\
\text { Desa Kediri } \\
\text { Kab. Lombok } \\
\text { Barat }\end{array}$ & $\begin{array}{l}\text { Pendidi } \\
\text { kan }\end{array}$ & $\begin{array}{l}\text { LOGO } \\
\text { YAYASA } \\
\mathrm{N} \\
\text { PENDIDI } \\
\text { KAN } \\
\text { CENDEK } \\
\text { IA } \\
\text { MATARA } \\
\text { M }\end{array}$ \\
\hline 24 & $\begin{array}{l}\text { FERDIAN } \\
\text { ELMANSY } \\
\text { AH }\end{array}$ & $\begin{array}{l}\text { Jl. KH.Agus } \\
\text { Salim No. } 1 \\
\text { Praya } \\
\text { Kabupaten } \\
\text { Lombok } \\
\text { Tengah }\end{array}$ & $\begin{array}{l}\text { Sambal } \\
\text { Kering } \\
\text { Siap } \\
\text { Saji }\end{array}$ & $\begin{array}{l}\text { MAIQ } \\
\text { MERES }\end{array}$ \\
\hline 25 & $\begin{array}{l}\text { RO'AYDA, } \\
\text { SE }\end{array}$ & $\begin{array}{l}\text { RW Dharma } \\
\text { Bhakti Desa } \\
\text { Rempung }\end{array}$ & $\begin{array}{l}\text { Olahan } \\
\text { Coklat }\end{array}$ & $\begin{array}{l}\text { CINTA } \\
\text { TIYARA }\end{array}$ \\
\hline
\end{tabular}

\begin{tabular}{|c|c|c|c|c|}
\hline & & $\begin{array}{l}\text { Kecamatan } \\
\text { Pringgasela } \\
\text { Kabupaten } \\
\text { Lombok } \\
\text { Timur }\end{array}$ & & \\
\hline 26 & MULYADI & $\begin{array}{l}\text { Dusun } \\
\text { Tanggak, } \\
\text { Desa } \\
\text { Masbagik } \\
\text { Timur } \\
\text { Kecamatan } \\
\text { Masbagik } \\
\text { Kab. Lombok } \\
\text { Timur NTB }\end{array}$ & $\begin{array}{l}\text { Tembik } \\
\text { ar }\end{array}$ & $\begin{array}{l}\text { MULYA } \\
\text { TREND }\end{array}$ \\
\hline 27 & $\begin{array}{l}\text { M. } \\
\text { KHAIRUL } \\
\text { IHWAN, } \\
\text { MT }\end{array}$ & $\begin{array}{l}\text { Puri Gelang } \\
\text { Indah Blok F4 } \\
\text { RT 006 Desa } \\
\text { Dasan Lekong } \\
\text { Kecamatan } \\
\text { Sukamulia } \\
\text { Kab.Lombok } \\
\text { Timur NTB } \\
\end{array}$ & $\begin{array}{l}\text { Mesin } \\
\text { Pertani } \\
\text { an }\end{array}$ & $\begin{array}{l}\text { ONDAK } \\
\text { JAYA }\end{array}$ \\
\hline 28 & MUHSIR & $\begin{array}{l}\text { Dusun } \\
\text { Benteng Desa } \\
\text { Kerumut } \\
\text { Kecamatan } \\
\text { Pringgabaya } \\
\text { Kabupaten } \\
\text { Lombok } \\
\text { Timur NTB }\end{array}$ & Kopi & LISENG \\
\hline 29 & $\begin{array}{l}\text { SYAIFUL } \\
\text { HADI }\end{array}$ & $\begin{array}{l}\text { Sekarteja RT } \\
\text { 005 Desa } \\
\text { Sekarteja } \\
\text { Kecamatan } \\
\text { Sukamulia } \\
\text { Kabupaten } \\
\text { Lombok } \\
\text { Timur NTB } \\
\end{array}$ & $\begin{array}{l}\text { Kursi } \\
\text { Bambu }\end{array}$ & $\begin{array}{l}\text { TRENK } \\
\text { ANKER }\end{array}$ \\
\hline 30 & MUSRI & $\begin{array}{l}\text { Dusun Cepak } \\
\text { Daya Desa } \\
\text { Aikmel } \\
\text { Kecamatan } \\
\text { Aikmel } \\
\text { Kabupaten } \\
\text { Lombok } \\
\text { Timur NTB } \\
\end{array}$ & $\begin{array}{l}\text { Keripik } \\
\text { Beras } \\
\text { Ketan }\end{array}$ & CEMARE \\
\hline 31 & $\begin{array}{l}\text { LALU } \\
\text { SUPRATM } \\
\text { AN }\end{array}$ & $\begin{array}{l}\text { Kampung } \\
\text { Dalem Lauq } \\
\text { RT 002 Desa } \\
\text { Lendang } \\
\text { Nangka } \\
\text { Kecamatan } \\
\text { Masbagik } \\
\text { Kab. Lombok } \\
\text { Timur NTB } \\
\end{array}$ & $\begin{array}{l}\text { Kerupu } \\
\text { k Ikan }\end{array}$ & $\begin{array}{l}\text { LENKAM } \\
\text { AS }\end{array}$ \\
\hline 32 & $\begin{array}{l}\text { MURTI } \\
\text { NEGARI }\end{array}$ & $\begin{array}{l}\text { Dusun Kenaot } \\
\text { Baru Desa } \\
\text { Suangi } \\
\text { Kecamatan } \\
\text { Sakra } \\
\text { Kabupaten } \\
\text { Lombok } \\
\text { Timur NTB }\end{array}$ & Garam & $\begin{array}{l}\text { RAJA } \\
\text { CERDAS }\end{array}$ \\
\hline 33 & $\begin{array}{l}\text { BAIQ IDA } \\
\text { LAELA }\end{array}$ & $\begin{array}{l}\text { Jl. Jenderal } \\
\text { Sudirman No. } \\
114 \text { Desa } \\
\text { Prapen } \\
\text { Kecamatan } \\
\text { Praya } \\
\text { Kabupaten } \\
\text { Lombok } \\
\text { Tengah NTB }\end{array}$ & $\begin{array}{l}\text { Kue } \\
\text { Gabus }\end{array}$ & D' LAEL \\
\hline
\end{tabular}




\begin{tabular}{|c|c|c|c|c|}
\hline 34 & $\begin{array}{l}\text { MANGGA } \\
\text { R, BA }\end{array}$ & $\begin{array}{l}\text { Buntereng } \\
\text { Desa Kawo } \\
\text { kecamatan } \\
\text { Pujut } \\
\text { Kabupaten } \\
\text { Lombok } \\
\text { Tengah NTB }\end{array}$ & $\begin{array}{l}\text { Kue } \\
\text { Kering } \\
\text { dan } \\
\text { Kerupu } \\
\text { k }\end{array}$ & $\begin{array}{l}\text { KEBUN } \\
\text { TETEH }\end{array}$ \\
\hline 35 & NURAENI & $\begin{array}{l}\text { Jl. Segara } \\
\text { Anak Km } 03 \\
\text { Kembang } \\
\text { Kerang Daya } \\
\text { Aikmel Kab. } \\
\text { Lombok } \\
\text { Timur }\end{array}$ & $\begin{array}{l}\text { Kain } \\
\text { Tenun }\end{array}$ & $\begin{array}{l}\text { PUTRI } \\
\text { AEGA }\end{array}$ \\
\hline
\end{tabular}

Sumber : Dinas Perindustrian Propinsi NTB tahun 2017

Dari data Industri Kecil Menengah (IKM) tahun 2016 di atas, sebanyak 35 orang atau pemilik Industri kecil dan menengah yang berupaya mendaftarkan kekayaan intelektualnya berupa hak merek kepada Direktorat Jenderal Kekayaan Intelektual melalui Kantor Kementerian Hukum dan Hak Asasi Manusia Nusa Tenggara Barat yang difasilitasi dan dikoordinir pendaftarannya oleh Dinas Perindustrian Propinsi Nusa Tenggara Barat, hal ini dilakukan oleh Industri dan Usaha Kecil Menengah dalam rangka untuk mendapatkan kepastian hukum akan keberadaan haknya dan bentuk pengakuan dari Negara akan hak kekayaan intelektual yang dimiliki oleh orang atau suatu badan hukum, karena dalam sistem UndangUndang Merek seseorang atau badan hukum baru akan mendapatkan perlindungan hukum khususnya terhadap hak Mereknya apabila terlebih dahulu didaftarkan oleh pemiliknya sesuai dengan prinsif konstitutif yang dianut atau diatur oleh Undang-Undang Nomor 15 Tahun 2001 sebagaimana telah rubah dengan Undang-Undang Nomor 20 Tahun 2016 Tentang Merek dan Indikasi Geografis.

Selain dari Merek terdapat juga kekayaan intelektual lainnya yaitu Desain Industri yang didaftarkan oleh Industri dan Usaha Kecil Menengah (IKM), namun jumlahnya yang sangat sedikit karena hingga penelitian ini selesai dilakukan hanya berjumlah 1 (satu) orang pendaftar Desain Industri saja dan dapat ditampilkan datanya sebagai berikut :

\begin{tabular}{|c|c|c|c|c|}
\hline No & Nama & Alamat & $\begin{array}{c}\text { Jenis } \\
\text { Prod } \\
\text { uk } \\
\end{array}$ & $\begin{array}{c}\text { Judul Desain } \\
\text { Industri }\end{array}$ \\
\hline 1. & $\begin{array}{l}\text { I Wayan } \\
\text { Suartana } \\
\text { Putra } \\
\text { Yasa }\end{array}$ & $\begin{array}{l}\text { Jl. R.A. } \\
\text { Kartini No. } \\
57 \text { A, Gubug } \\
\text { Batu, Kel. } \\
\text { Monjok } \\
\text { Timur, } \\
\text { Kecamatan } \\
\text { Selaparang, } \\
\text { Kota } \\
\text { Mataram } \\
\text { NTB }\end{array}$ & $\begin{array}{l}\text { Keraji } \\
\text { nan }\end{array}$ & \begin{tabular}{ll}
\multicolumn{2}{l}{ Kupu-kupu } \\
dari & batok \\
kelapa &
\end{tabular} \\
\hline
\end{tabular}

Sumber : Dinas Perindustrian Propinsi Nusa Tenggara Barat tahun 2017.

Berdasarkan wawancara dengan Evy Djulaeha, ${ }^{7}$ bahwa Industri Kecil dan Menengah paling banyak yang mendaftarkan Merek sebagai tanda atau symbol untuk perdagangan barang yang diproduksinya, sehingga untuk kekayaan intelektual jenis lain masih kurang seperti untuk desain industry hanya 1 (satu) pendaftar untuk tahun 2016 bahkan untuk tahun 2017 tidak ada pendaftar, apalagi untuk bidang atau jenis kekayaan intelektual lainnya tidak ada permohonan pendaftaran.

Kemudian untuk data pendaftaran Kekayaan Intelektual tahun 2017, peneliti mendapatkan data rekapitulasi jumlah Industri Kecil dan Menengah yang mendaftarkan kekayaan intelektual hanya berupa Merek saja dan dapat ditampilkan sebagai berikut :

\begin{tabular}{cllc}
\hline No & NAMA & \multicolumn{1}{c}{ ALAMAT } & MEREK \\
\hline & $\begin{array}{l}\text { Ida } \\
\text { Tirtas } \\
\text { ari } \\
\text { Nasut } \\
\text { ion }\end{array}$ & $\begin{array}{l}\text { Perum Taman Mutiara } \\
\text { Kav.18 Pagutan Barat } \\
\text { Mataram }\end{array}$ & Ayibba \\
& $\begin{array}{l}\text { Nini } \\
\text { Suhai } \\
\text { ni }\end{array}$ & $\begin{array}{l}\text { Jl.Serayu I Blok C,61,Rt } \\
\text { 011, Kel. Pagesangan Barat, } \\
\text { Mataram, NTB }\end{array}$ & Sinar \\
& $\begin{array}{l}\text { Sani } \\
\text { Karmi }\end{array}$ & $\begin{array}{l}\text { Lingkungan Karang Pule Rt } \\
\text { 004 Rw 172 Kel, Karang }\end{array}$ & Kumpul \\
la & Pule Kec, Sekarbela & Sekeq \\
\hline & & Kota Mataram Provinsi & \\
& & NTB & \\
\hline & Yeni & Puri Bunga Amanah Block & \\
4. & Irmay & B/10 Rk Jangkuk & Irmaya Bag \\
& a & Rt/Rw.007/132 Sayang- & \\
\hline
\end{tabular}

${ }^{7}$ Evy Djualaeha, Kasi Industri Kreatif Dinas Perindustrian Propinsi NTB, tanggal 4 September 2017 


\begin{tabular}{|c|c|c|c|}
\hline & & \multicolumn{2}{|l|}{ Sayang } \\
\hline & & Cakranegara Mataram,NTB & \\
\hline 5. & $\begin{array}{l}\text { Minar } \\
\text { ty } \\
\text { Sastri } \\
\text { na }\end{array}$ & $\begin{array}{l}\text { Bendega, Rt 006, Rw 181, } \\
\text { Tanjung Karang, Kec. } \\
\text { Sekarbela, Kota Mataram, } \\
\text { NTB }\end{array}$ & Bombok \\
\hline 6. & $\begin{array}{l}\text { Nani } \\
\text { Qoma } \\
\text { riyah } \\
\end{array}$ & $\begin{array}{l}\text { Jl.Jend.Sudirman Gg. Jawa } \\
\text { No } 8 \text { Rembiga, Kota } \\
\text { Mataram, NTB } \\
\end{array}$ & Nikq \\
\hline 7. & $\begin{array}{l}\text { Fajrin } \\
\text { Ridya } \\
\text { nsah } \\
\text { Halil, } \\
\text { s. St. } \\
\text { Pi } \\
\end{array}$ & $\begin{array}{l}\text { J1.Sandubaya Rt } 004 \text { Rw } \\
\text { 002 Kelurahan Bertais Kec. } \\
\text { Sandubaya Kota Mataram } \\
\text { NTB }\end{array}$ & Minafood \\
\hline 8. & $\begin{array}{l}\text { Annis } \\
\text { a } \\
\text { Raida } \\
\text { tul } \\
\text { Janna } \\
\text { h } \\
\end{array}$ & $\begin{array}{l}\text { Jl. Bambu Runcing I No. } 10 \\
\text { Rt. } 003 \text { Rw. } 017 \\
\text { Kel.Pejeruk, Kec. Ampenan, } \\
\text { Kota Mataram, NTB }\end{array}$ & Selo \\
\hline 9. & $\begin{array}{l}\text { Baiq } \\
\text { Finart } \\
\text { i }\end{array}$ & $\begin{array}{l}\text { Dusun Gubuk Alang Rt } 002 \text {, } \\
\text { Kopang Rembiga, Lombok } \\
\text { Tengah, NTB }\end{array}$ & Finarti \\
\hline 10. & $\begin{array}{l}\text { Lalu } \\
\text { Ungg } \\
\text { ul } \\
\text { Umba } \\
\text { li } \\
\end{array}$ & $\begin{array}{l}\text { Dusun Camplung, Desa } \\
\text { Jelantik, Kec. Jonggat Kab. } \\
\text { Lombok Tengah }\end{array}$ & $\begin{array}{l}\text { Sambel } \\
\text { Bengak ( } \\
\text { Banteng } \\
\text { Ngangak ) }\end{array}$ \\
\hline 11. & $\begin{array}{l}\text { Ferdia } \\
\mathrm{n} \\
\text { Elma } \\
\text { nsyah }\end{array}$ & $\begin{array}{l}\text { Jl. KH. Agus Salim, No. } 1 \\
\text { Praya }\end{array}$ & $\begin{array}{l}\text { Sambal } \\
\text { Cengeh }\end{array}$ \\
\hline 12. & $\begin{array}{l}\text { Baiq } \\
\text { Dea } \\
\text { Novit } \\
\text { a } \\
\text { Ratm } \\
\text { adina } \\
\end{array}$ & $\begin{array}{l}\text { Dusun Camplung, Desa } \\
\text { Jelantik, Kec. Jonggat Kab. } \\
\text { Lombok Tengah, NTB }\end{array}$ & Gili \\
\hline 13. & $\begin{array}{l}\text { Mursi } \\
\text { di }\end{array}$ & $\begin{array}{l}\text { Dusun Kebun Tengak, Rt } \\
\text { 002, Desa Gemel, Lombok } \\
\text { Tengah, NTB }\end{array}$ & $\begin{array}{c}\text { Bunut } \\
\text { Pansek } \\
\text { Lombok }\end{array}$ \\
\hline 14. & $\begin{array}{l}\text { Sri } \\
\text { Sofiat } \\
\text { i } \\
\text { Soleh } \\
\text { aton }\end{array}$ & $\begin{array}{l}\text { Pedaleman Dusun Kopang } \\
\text { II, Desa Kopang Rembiga, } \\
\text { Kec, Kopang, Lombok } \\
\text { Tengah, NTB }\end{array}$ & $\begin{array}{c}\text { Rudat } \\
\text { Lombok }\end{array}$ \\
\hline 15. & $\begin{array}{l}\text { Happ } \\
\text { y } \\
\text { Puspit } \\
\text { asri } \\
\end{array}$ & $\begin{array}{l}\text { Jl.Kartini No. } 3 \text { Rt. } 005 \\
\text { Dusun Griya Asri Desa } \\
\text { Jatisela Kec. Gunung Sari } \\
\text { Lombok Barat, NTB }\end{array}$ & Prime 79 \\
\hline 16. & $\begin{array}{l}\text { Maru } \\
\text { din }\end{array}$ & $\begin{array}{l}\text { Longserang Barat Utara, } \\
\text { Desa Langko Kec. Lingsar, } \\
\text { Lombom Barat, NTB }\end{array}$ & Enauqu \\
\hline 17. & $\begin{array}{l}\text { Sylvia } \\
\text { Sri } \\
\text { Oetari }\end{array}$ & $\begin{array}{l}\text { Jl. Ruby P. Perumahan } \\
\text { Bumin Selaparang Asri, } \\
\text { Midang, Gunungsari } \\
\text { Lombok Barat, NTB } \\
\end{array}$ & $\begin{array}{l}\text { Sylvia } \\
\text { Jewelry }\end{array}$ \\
\hline 18. & $\begin{array}{l}\text { Cv. } \\
\text { Embu } \\
\mathrm{n}\end{array}$ & $\begin{array}{l}\text { Jl. Jendral Ahmad Yani No. } \\
54 \text { Narmada }\end{array}$ & Aijerning \\
\hline 19. & Ramli & $\begin{array}{l}\text { Dusun Gelogor Selatan, } \\
\text { Kediri, Lombok Barat, NTB }\end{array}$ & Pade Mauq \\
\hline 20. & $\begin{array}{l}\text { Syifa } \\
\text { Hasyi } \\
\text { em }\end{array}$ & $\begin{array}{l}\text { Jl. Raya Gunungsari - } \\
\text { Tanjung Km2 No.1, Kekait - } \\
\text { Gunungsari Lombok Barat, } \\
\text { NTB }\end{array}$ & Boan \\
\hline
\end{tabular}

\begin{tabular}{|c|c|c|c|}
\hline 21. & $\begin{array}{l}\text { H. } \\
\text { Saraf } \\
\text { uddin }\end{array}$ & $\begin{array}{l}\text { Dusun Barat Kokok Desa } \\
\text { Guntur Macan Kec. } \\
\text { Gunungsari Kab. Lombok } \\
\text { Barat }\end{array}$ & $\begin{array}{l}\text { Kecial } \\
\text { Kuning }\end{array}$ \\
\hline 22. & $\begin{array}{l}\text { Hasyi } \\
\text { em, } \\
\text { BSc }\end{array}$ & $\begin{array}{l}\text { Jl. Raya Gunungsari - } \\
\text { Tanjung Km2 No.1, Kekait - } \\
\text { Gunungsari Lombok Barat, } \\
\text { NTB }\end{array}$ & Al Buruj \\
\hline 23. & $\begin{array}{l}\text { Choir } \\
\text { ul } \\
\text { Yakin }\end{array}$ & $\begin{array}{l}\text { Dusun Ketirek Desa } \\
\text { Jembatan Gantung Rt. } 005 \\
\text { Kec. Lembar Kab, Lombok } \\
\text { Barat, NTB }\end{array}$ & Faeziela \\
\hline 24. & $\begin{array}{l}\text { Abdul } \\
\text { Rahi } \\
\mathrm{m} \\
\end{array}$ & $\begin{array}{l}\text { Gubuk Baru, Mt. Kandik } \\
\text { Desa Terara, Kec. Terara }\end{array}$ & $\begin{array}{c}\text { Maiq } \\
\text { Manget } \\
\text { Meres }\end{array}$ \\
\hline 25. & $\begin{array}{l}\text { Khari } \\
\text { s } \\
\text { Cahya } \\
\text { di }\end{array}$ & $\begin{array}{l}\text { Jl. Diponegoro No. 22B } \\
\text { Selong Lombok Timur, } \\
\text { NTB }\end{array}$ & Kribrow \\
\hline 26. & $\begin{array}{l}\text { Murni } \\
\text { hati }\end{array}$ & $\begin{array}{l}\text { Jor Desa Jerowaru Kec. } \\
\text { Jerowaru Lombok Timur, } \\
\text { NTB }\end{array}$ & Gujorat \\
\hline 27. & $\begin{array}{l}\text { Nur } \\
\text { Janna } \\
\text { h }\end{array}$ & $\begin{array}{l}\text { Dusun Menggala Lauk } \\
\text { Pemenang Barat Lombok } \\
\text { Utara, NTB }\end{array}$ & Glistanta \\
\hline 28. & $\begin{array}{l}\text { Husna } \\
\text { ini }\end{array}$ & $\begin{array}{l}\text { Dusun Lendang Berora, Rt } \\
\text { 002, Kel. Sigar Penjalin, } \\
\text { Kec. Tanjung, Lombok } \\
\text { Utara, NTB }\end{array}$ & $\begin{array}{l}\text { Cahaya } \\
\text { Riski }\end{array}$ \\
\hline 29. & Septi & $\begin{array}{l}\text { Dusun Karang Baru Rt. } 001 \\
\text { Kel. Pemenang Timur Kec. } \\
\text { Pemenang Kab. Lombok } \\
\text { Utara }\end{array}$ & $\begin{array}{l}\text { Cheftihand } \\
\text { ycraft }\end{array}$ \\
\hline 30. & $\begin{array}{l}\text { Muni } \\
\text { ah }\end{array}$ & $\begin{array}{l}\text { Santong Suka Damai, } \\
\text { Lombok Utara, NTB }\end{array}$ & $\begin{array}{c}\text { Elvin } \\
\text { Santong } \\
\text { Bersinar } \\
\end{array}$ \\
\hline 31. & $\begin{array}{l}\text { Wiwi } \\
\text { Arian } \\
\text { y, } \\
\text { S.Pd }\end{array}$ & $\begin{array}{l}\text { Link. Selayar Rt } 001 \text { Rw } \\
\text { 004 Desa Dalam Kec. } \\
\text { Taliwang }\end{array}$ & Wai \\
\hline 32. & $\begin{array}{l}\text { Syahr } \\
\text { uddin }\end{array}$ & $\begin{array}{l}\text { Jl. Kartini Gg Puyuh Rt/Rw. } \\
\text { 002/003. Kel. Barang Bara } \\
\text { Kec. Sumbawa, NTB }\end{array}$ & $\begin{array}{l}\text { Samawa } \\
\text { Inspiration }\end{array}$ \\
\hline 33. & Arina & $\begin{array}{l}\text { Dusun Taropo Rt 001, Desa } \\
\text { Taropo, Kec. Kilo, Dompu } \\
\text { NTB }\end{array}$ & Afaj \\
\hline 34. & $\begin{array}{l}\text { Ludya } \\
\mathrm{h}\end{array}$ & $\begin{array}{l}\text { Jl. Kepiting Rt } 006 \text { Rw } 003 \\
\text { Kel. Melayu Kec. AsaKota } \\
\text { Kota Bima, NTB }\end{array}$ & $\begin{array}{l}\text { La Melo } \\
\text { Food }\end{array}$ \\
\hline 35. & $\begin{array}{l}\text { Khair } \\
\text { unnas }\end{array}$ & $\begin{array}{l}\text { Rada, Rt/Rw. 006/ 002. } \\
\text { Desa Rada Kec. Bolo Kab. } \\
\text { Bima, NTB }\end{array}$ & Lamonda \\
\hline
\end{tabular}

Sumber : Dinas Perindustrian Propinsi NTB tahun 2017

Ketentuan Umum Pasal 1 (angka 1) Undang-Undang Merek dan Indikasi Geografis, mendefinisikan Merek adalah tanda yang dapat ditampilkan secara grafis berupa gambar, logo, nama, kata, huruf, angka, susunan warna, dalam bentuk 2 (dua) dimensi dan/atau 3 (tiga) dimensi, suara, hologram, atau kombinasi dari 2 (dua) atau lebih unsur tersebut untuk membedakan barang dan/atau jasa yang diproduksi oleh orang atau badan hukum 
dalam kegiatan perdagangan barang dan/atau jasa

Berdasarkan pada ketentuan umum Pasal 1 (angka 1) di atas, maka merek yang digunakan oleh pelaku usaha atau industry kecil dan menengah dapat digolongkan menjadi beberapa merek yaitu (1) Merek Dagang adalah merek yang digunakan pada barang yang diperdagangkan oleh seseorang atau beberapa orang secara bersama-sama atau badan hukum untuk membedakan dengan barang-barang sejenis lainnya. (2) Merek jasa adalah merek yang digunakan pada jasa yang diperdagangan oleh seseorang atau beberapa orang secara bersama-sama atau badan hokum untuk membedakan dengan jasa-jasa sejenis lainnya. (3) Merek Kolektif adalah merek yang digunakan pada barang dan atau jasa dengan karakteristik yang sama yang diperdagangkan oleh beberapa orang atau badan hokum secara bersama-sama untuk membedakan dengan barang/atau jasa sejenis lainnya.

Perlindungan hukum terhadap Merek dan Desain Industri melalui pendaftaran merupakan salah satu cara untuk memperkuat sistem dalam pengekploitasian dan komersialisasi serta untuk menciptakan persaingan usaha yang sehat. Para pemilik Merek dan Desain Industri yang sudah terdaftar akan mendapatkan Hak Merek dan Hak Desain Industri, yaitu berupa hak eksklusif yang diberikan oleh Negara kepada pemilik merek dan desain industri terdaftar dalam Daftar Umum Merek/Desain Industri untuk dalam jangka waktu tertentu menggunakan sendiri merek atau desain industri tersebut atau memberikan lisensi atau izin kepada pihak lain. Berdasarkan hak Merek dan hak desain industry tersebut para pemilik merek dan desain industry termasuk dalam hal ini Industri Kecil dan Menengah akan mendapatkan perlindungan hukum sehingga dapat mengembangkan usahanya dengan tenang tanpa takut Merek dan
Desainnya diklaim oleh pihak lain. Pemberian lisensi merek dan desain industry kepada pihak lain dapat mendatangkan penghasilan berupa pembayaran royalty.

Tumbuhnya kreativitas masyarakat yang dituangkan dalam berbagai bentuk dan wujud baik di bidang Hak Merek, Hak Desain Industry dan mungkin hak kekayaan intelektual lainnya seperti Hak Cipta, Rahasia Dagang, Hak Paten, Hak Desain Tata Letak Sirkuit Terpadu dan Varitas Tanaman menunjukan masyarakat yang ada di Pulau Lombok sebenarnya mempunyai potensi untuk dapat memiliki kekayaan intelektual yang dapat dikembangkan dalam meningkatkan ekonomi maupun keunggulan dirinya. Timbulnya berbagai karya-karya dan kekayaan intelektual yang dihasilkan masyarakat pada akhirnya menimbulkan kebutuhan untuk melindungi atau mempertahankan kekayaan tersebut. Pada gilirannya, akan melahirkan upaya atau tindakan perlindungan hukum melalui rezim hukum hak kekayaan intelektual baik melalui merek, desain industry, hak cipta, hak paten dan rezim hak kekayaan intelektual lainnya agar mendapat pengakuan hak sesuai aturan atau hukum di Indonesia.

Dari sudut padang Hukum Hak Kekayaan Intelektual, penumbuhan aturan tersebut karena adanya kewajiban bagi pemilik kekayaan intelektual untuk mendaftarkan kekayaan intelektualnya ke instansi berwenang dalam hal ini Direktur Jenderal Kekayaan Intelektual Republik Indonesia diperlukan karena akan adanya penghargaan, penghormatan dan perlindungan tidak saja akan memberikan rasa aman kepada pemilik hak kekayaan intelektual, tetapi juga akan mewujudkan iklim yang kondusif bagi peningkatan semangat untuk menghasilkan karya-karya yang lebih besar, lebih baik dan lebih banyak.

Jika dilihat dari sisi nasional, dimana 
manusia Indonesia berperan sebagai pelaku usaha baik industry kecil dan menengah, serta meningkatnya profesionalisme dan produktivitasnya merupakan sesuatu yang benar-benar ingin diwujudkan, maka penumbuhan dan pengembangan Hak Kekayaan Intelektual dalam sistem di Indonesia memiliki arti yang penting. Konkretnya dari berbagai jenis Hak Kekayaan Intelektual yang ada seperti merek, desain industry dan paten, maka industry kecil dan menengah dapat memproteksi kekayaan intelektual yang dihasilkannya melalui salah satu dari jenis hak kekayaan intelektual tersebut sesuai dengan prinsif hukum hak kekayaan intelektual yaitu prinsip konstitutif dan deklaratif. Sasaran kehidupan masyarakat yang seimbang jika terdapat kehidupan ekonomi yang seimbang pula, dalam kaitan dengan industry maka akan tercipta salah satu tatanan ekonomi industry yang bertumpu atau berbasis pada kekayaan intelektual

Fungsi hukum hak kekayaan intelektual.hendaknya diwujudkan dalam fungsi proteksi (perlindungan) agar adanya pengakuan negara terhadap hak tersebut tentang untuk dan dalam waktu tertentu dapat dieksploitasi atau dinikmati sendiri kekayaan tersebut oleh pemiliknya. Selama kurun waktu tertentu orang lain hanya dapat menikmati atau menggunakan serta mengeksploitasi hak tersebut atas izin pemilik hak, karenanya proteksi dan pengakuan hak tersebut hanya diberikan khusus kepada orang yang memiliki kekayaan tadi, atau diberikan hak eksklusif kepada pemiliknya.

Fungsi hukum untuk melindungi sebagaimana tersebut di atas dimaksudkan agar pemilik hak dapat menggunakan atau mengeksploitasi kekayaan tersebut dengan aman. Pada gilirannya, rasa aman itulah yang kemudian menciptakan iklim atau suasana yang memungkinkan orang dapat berkarya guna menghasilkan suatu ciptaan atau penemuan berikutnya. Sebaliknya, dengan perlindungan hukum pula, pemilik hak diminta untuk mengungkap jenis, bentuk dan cara kerja serta manfaat dari kekayaan intelektual tersebut. Ia dapat aman mengungkapkan (discloses) karena adanya jaminan perlindungan hukum, sebaliknya masyarakat dapat ikut menikmati atau menggunakan atas dasar izin atau bahkan mengembangkannya secara lebih lanjut.

Dalam hal ini hukum bukan hanya berfungsi mendisplinerkan ekonomi, tetapi terwujud dalam kegiatan-kegiatan ekonomi itu sendiri baik yang dilakukan oleh industry dan usaha kecil menengah. Ini berarti bahwa kehadiran sistem peraturan (hukum) merupakan syarat mutlak untuk dapat berlangsungnya kegiatan ekonomi atau bisnis. Untuk menjaga keseimbangan kepentingan pribadi individu dengan kepentingan masyarakat, sistem hak kekayaan intelektual didasarkan pada prinsip-prinsip antara lain, prinsip keadilan (the principal of natural justice). ${ }^{8}$ Prinsip ini menunjukkan bahwa seseorang atau kelompok pencipta sebuah karya atau penemu sebuah penemuan ataupun orang lain yang bekerja padanya, yang membuahkan hasil dari kemampuan intelektualnya wajar memperoleh imbalan. Imbalan tersebut dapat merupakan materi maupun bukan materi seperti adanya rasa aman karena dilindungi dan diakui atas hasil karyanya. Hukum memberikan perlindungan tersebut demi kepentingan pencipta atau penemu invensi berupa suatu kekuasaan untuk bertindak dalam rangka kepentingannya tersebut yaitu yang disebut hak.

Setiap hak menurut hukum tersebut mempunyai titel, yaitu sebagai suatu peristiwa tertentu yang dapat menjadi alasan melekatnya hak itu kepada pemiliknya. Berkaitan dalam bidang hak kekayaan intelektual, maka peristiwa yang

8 Suyud Margono, Aspek Hukum Komersialisasi Aset Intelektual, CV. Nuansa Aulia, Bandung, 2010, hal. 5 
menjadi alasan melekatnya hak itu adalah penciptaan atau penemuan invensi yang berdasarkan atas kemampuan intelektualnya. Perlindungan inipun tidak terbatas di dalam negeri si pencipta atau penemu itu sendiri, melainkan juga dapat meliputi perlindungan di luar yuridiksi Negaranya. Hukum berpengaruh pada kehidupan ekonomi dalam bentuk pemberian norma-norma yang mengatur tindakan-tindakan ekonomi yang dilakukan oleh pelaku usaha baik industry ataupun pelaku usaha kecil dan menengah membutuhkan peraturan-peraturan untuk mengendalikan perbuatan diantara para pihak. Agar optimasi penyelenggaraan kesejahteraan masyarakat dapat tercapai dengan tertib, tanpa menimbulkan kekacauan.

\section{Mekanisme Perlindungan Hukum} dalam Kegiatan Eksploitasi dan Komersialisasi Kekayaan Intelektual Oleh Industri dan Usaha Kecil Menengah

Dalam tatanan perekonomian global, aturan perlindungan hak kekayaan intelektual dan segala aspeknya dalam perdagangan sudah menjadi aturan main dengan disetujuinya persetujuan TRIPs (Agreement Trade Related Intellectual Property Rights) yang telah menjadi bagian dalam persetujuan pembentukan organisasi perdagangan dunia (Agreement Establising the World Trade Organization). Dalam kenyataan yang harus disadari bahwa dengan keikutsertaan Indonesia dalam WTO telah memberikan arti bahwa posisi Indonesia adalah sama dengan Negara lain yang mau tidak mau harus siap dengan kompetisi dalam pasar global.

Demikian juga dalam hal eksploitasi dan komersialisasi kekayaan intelektual sebagai asset bisnis bagi dunia industry atau pelaku usaha baik kecil, menengah maupun besar, karena harus tunduk pada hukum pasar. Pelaku usaha akan melakukan eksploitasi dan komersialisasi
Hak kekayaan intelektual apabila biaya produksi marginal untuk produk-produk yang bermuatan hak kekayaan intelektual lebih kecil dari harga jual. Kompetisi usaha yang sehat dan adanya permintaan dan daya beli yang tinggi, karenanya merupakan pendorong utama bagi dilakukannya eksploitasi dan komersialisasi hak kekayaan intelektual ini.

Karya-karya intelektual hanya akan tumbuh subur pada masyarakat yang memiliki budaya mencipta yang tinggi, sedangkan budaya mencipta tersebut akan tumbuh berkembang apabila masyarakat tersebut memberikan pengakuan dan penghargaan yang layak dan memadai kepada karya-karya intelektual, pengakuan dan penghargaan yang memadai terhadap hak kekayaan intelektual merupakan syarat mutlak.

Untuk meningkatkan budaya kreatif yang penuh inovasi setidaknya harus terdapat motif atau inisiatif utama yang menghasilkan ciptaan atau penemuan, yang antara lain : ${ }^{9}$

1) Kesenangan melakukan kegiatan penemuan (love to invent);

2) Hasrat untuk melakukan pembaharuan (desire to improve);

3) Perolehan keuntungan (financial gain);

4) Dorongan kebutuhan (necessity);

5) Hasrat untuk berprestasi (desire to achieve);

6) Bagian dari pekerjaan (part of works);

7) Prestise (prestige).

Meskipun dilihat dari hierarki motif di atas, motif mencari keuntungan finansial menempati urutan ketiga, tidak dapat disangkal bahwa motif mencari keuntungan (profit motive) merupakan faktor utama yang mendorong dilakukannya eksploitasi dan komersialisasi hak kekayaan intelektual. Eksploitasi dan komersialisasi hak

\footnotetext{
${ }^{9}$ Ibid, hal 33
} 
kekayaan intelektual, karenanya tunduk pada hukum pasar. Pengusaha akan melakukan eksploitasi dan komersialisasi hak kekayaan intelektual apabila biaya produksi marginal untuk produk-produk yang bermuatan hak kekayaan intelektual lebih kecil dari harga jual. Kompetisi usaha yang sehat dan adanya permintaan dan daya beli yang tinggi, karenanya merupakan pendorong utama bagi dilakukannya eksploitasi dan komersialisasi hak kekayaan intelektual.

Sistem hukum hak kekayaan intelektual harus mampu menciptakan iklim yang kondusif bagi usaha ekploitasi dan komersialisasi karya-karya intelektual yang bermuatan Hak kekayaan intelektual. Sistem hukum hak kekayaan intelektual misalnya harus mampu menekan serendah mungkin biaya-biaya hukum (legal cost) dalam pengurusan pendaftaran dan pengalihan hak kekayaan intelektual maupun biaya-biaya kontrak (transaction cost) yang berkaitan dengan lisensi (licensing), usaha patungan (joint venture) maupun waralaba (franchising).

Terdapat beberapa mekanisme perlindungan hukum dalam eksploitasi dan komersialisasi hak kekayaan intelektual yang dimiliki oleh industry dan usaha kecil menengah yaitu :

\section{Pengalihan hak melalui jual beli}

Salah satu cara untuk mengekploitasi dan komersialisasi hak kekayaan intelektual yang dimiliki oleh Industri dan usaha kecil menengah adalah dengan cara atau mekanisme konstruksi hukum jual beli. Sebagai contoh yang mudah dan sering dilakukan oleh para pemilik kekayaan intelektual seperti kreator dan penemu yaitu seorang penulis mengalihkan hak ciptanya (copyright) kepada penerbit yang kemudian penerbit menyuplai segi teknis dan kewirausahaannya, menyebarluaskan buku tersebut kepada pasar atau konsumen. Hal ini juga sama dengan penulis lagu yang juga mengalihkan hak cipta dalam bentuk musical work-nya kepada sebuah recording company. Peralatan dari mesin-mesin, seperti perlengkapan motor mungkin terdapat banyak bagian-bagian dari paten yang dijual oleh perusahaan-perusahaan berbeda.

Demikian juga dengan pendesain yang mempunyai desain terhadap suatu produk desain pakaian, desain kerajinan dan desain perhiasan, maka pendesain kalau tidak dapat mengekploitasi sendiri kekayaan intelektual berupa hasil desainnya maka pendesain dapat menjual desain tersebut ke pihak produsen atau perusahaan yang mau memproduksi desain-desain tersebut dengan segala peralatan dan sumber daya yang dimiliki oleh produsen atau perusahaan tersebut untuk kemudian memasarkannya langsung ke konsumen. Demikian juga bagi industry dan usaha kecil menengah yang mempunyai hak kekayaan intelektual baik di bidang paten, merek, desain tata letak sirkuit terpadu ataupun rahasia dagang dapat melakukan tindakan demikian, hal ini dimaksudkan dalam kerangka pelindungan hukum agar terciptanya kepastian hukum dalam penggunaan atau pemanfaatan kekayaan intelektual guna mendapatkan kemanfaatan atau keuntungan ekonomi yang sesuai dengan nilai-nilai kepatutan dan sesuai dengan prinsip eksklusifitas dalam rezim hak kekayaan intelektual.

Semua ini menggambarkan bahwa hak kekayaan intelektual yang dimiliki oleh industry dan usaha kecil menengah berkedudukan sebagai benda atau barang yang tidak bergerak sehingga dapat dijual atau dibeli karenanya berlaku hukum jual beli sebagai salah satu mekanisme dalam perlindungan hukum yang dapat dilakukan oleh setiap pelaku usaha atau industry baik usaha kecil dan menengah dalam mengekploitasi dan mengkomersialisasi setiap hak kekayaan intelektual yang dimilikinya.

Jual beli menurut Pasal 1457 KUH 
Perdata adalah suatu perjanjian dengan mana pihak yang satu mengikatkan dirinya untuk menyerahkan suatu benda dan pihak lain membayar harga yang telah dijanjikan. Dalam hukum barat, jual beli dianggap telah terjadi antara kedua belah pihak pada saat mereka mencapai kata sepakat mengenai harga yang diperjualbelikan sesuai dengan Pasal 1458 KUH Perdata; "jual beli itu dianggap telah terjadi antara kedua belah pihak, seketika setelahnya orang-orang ini mencapai sepakat tentang kebendaan tersebut dan harganya meskipun kebendaan itu belum diserahkan, maupun harganya belum dibayar".

Jual beli bersifat konsensuil artinya dalam peristiwa jual beli ada telah lahir dan mengikat para pihak. Yaitu penjual dan pembeli segera setelah mereka mencapai kata sepakat mengenai kebendaan yang diperjualbelikan dan harga yang harus dibayar. Dengan kesepakatan tersebut, pembeli berkewajiban untuk membayar harga pembelian dan penjual terikat untuk menyerahkan kebendaan yang dijual tersebut. Dalam hubungannya dengan penyerahan hak milik ini maka perlu diperhatikan ketentuan Pasal 584 KUH Perdata yang menyatakan bahwa "hak milik atas suatu benda tidak dapat diperoleh dengan cara lain melainkan dengan cara pemilikan (pendakuan), karena perlekatan, daluarsa, pewarisan baik menurut undang-undang maupun surat wasiat dan dengan penunjukan maupun penyerahan berdasarkan suatu peristiwa perdata untuk pemindahan hak milik, dilakukan oleh orang yang berhak untuk berbuat bebas terhadap barang itu.

Tujuan dari diadakannya suatu proses jual beli adalah untuk mengalihkan hak milik atas kebendaan yang dijual. Dari ketentuan Pasal 584, tersebut maka secara mutlak cara untuk memperoleh hak milik tersebut adalah dengan kelima cara sebagaimana yang telah disebutkan di atas. Ketentuan dari Pasal 584 tersebut yang menyatakan bahwa hak milik atas kebendaan tersebut dapat diperoleh dengan penyerahan berdasarkan atas suatu peristiwa perdata. Untuk memindahkan hak milik, dilakukan oleh seseorang yang berhak berbuat bebas terhadap kebendaan itu. Ketentuan tersebut mensyaratkan bahwa untuk memperoleh hak milik berdasarkan penyerahan harus memenuhi 2 (dua) syarat yaitu : 1). Adanya peristiwa perdata untuk memindahkan hak milik; 2). Dilakukan penyerahan. ${ }^{10}$

Dalam Undang-Undang tentang Hak Kekayaan intelektual diatur bahwa dalam penjualan atau pembelian hak kekayaan intelektual mensyaratkan beberapa persyaratan formal sebagai contohnya pengalihan hak dalam bentuk jual beli ini harus dalam bentuk tertulis, ditandatangani oleh kedua belah pihak (penjual dan pembeli) dan didaftarkan pada kantor pemerintah yang berwenang dalam hal ini Departemen Hukum dan Hak Asasi Manusia Republik Indonesia. Selanjutnya sebuah harga pembelian berkaitan dengan jumlah uang, dimana perjanjian jual beli dapat dilakukan secara lepas untuk sekali transaksi sehingga pemilik kekayaan intelektual (pencipta, pendesain, pemilik merek, pemulia tanaman dan jenis kekayaan intelektual lainnya) akan kehilangan hak dan akan berpindah ke pihak pembeli, ataupun dengan sistem pembayaran royalty untuk periode waktu tertentu selama hak kekayaan intelektual tersebut dieksploitasi oleh pihak lain.

\section{Lisensi (Ijin Pemafaatan Hak)}

Lisensi hak kekayaan intelektual (HKI) berhubungan dengan nilai ekonomi yang melekat pada karya intelektual dan melekat hak eksklusif bagi pemiliknya. Berdasar hak tersebut, pemilik HKI dapat melaksanakan sendiri atau melarang orang lain melakukan eksploitasi HKI (guna memperoleh nilai materiil) tanpa persetujuan pemiliknya. Komersialisasi

${ }^{10}$ I Made Somya Putra, Perjanjian Jual Beli, https;//www.google.co.id, diakses tanggal 1 Oktober 2017 
HKI merupakan jalan untuk mendapatkan nilai materiil tersebut. Caranya, dapat dilakukan dengan berbagai upaya antara lain melalui penjualan aset (ingat bahwa HKI merupakan aset), lisensi, maupun waralaba. Bagi pemilik HKI, sebelum melakukan komersialisasi sebaiknya memahami hukum perjanjian.

Pasal 1320 Kitab Undang-Undang Hukum Perdata memberikan tuntunan untuk melakukan perjanjian. Menurut pasal tersebut, terdapat 2 (dua) syarat pokok dalam melakukan perjanjian yaitu syarat subyektif dan syarat obyektif. Syarat subyektif menunjuk adanya kesepakatan bagi para pihak untuk mengikatkan diri, artinya dalam suatu perjanjian tidak diperkenankan adanya unsur paksaan, penipuan maupun kekhilafan. Persyaratan subyektif lainnya adalah adanya kecakapan para pihak untuk melakukan perjanjian. Artinya, para pihak telah dewasa serta tidak di bawah pengampuan/perwalian sedangkan mengenai obyek yang diperjanjikan sebagai syarat obyektif meliputi adanya suatu hal tertentu dan suatu sebab yang halal. Syarat adanya suatu hal tertentu adalah bahwa suatu perjanjian mempunyai obyek yang ditentukan berupa benda yang ada maupun yang akan ada (Pasal 1332-1335 KUHPerdata) sedangkan persyaratan adanya suatu sebab yang halal adalah berkaitan dengan kesusilaan, ketertiban umum dan tidak bertentangan dengan undang- undang (Pasal 1337 KUHPerdata).

Guna memperoleh keuntungan yang lebih banyak, Pemilik HKI dapat memberikan lisensi kepada lebih dari satu pihak kecuali diperjanjikan. Artinya, apabila telah diperjanjikan bahwa pemilik HKI tidak akan memberikan lisensi berikutnya kepada pihak lain, maka ia harus mematuhi perjanjian tersebut. Di Indonesia, perjanjian lisensi di bidang HKI, prinsip dasar yang paling utama adalah tidak bertentangan dengan kepentingan ekonomi Indonesia dan dilarang memuat ketentuan pembatasanpembatasan yang menghambat kemampuan bangsa Indonesia dalam menguasai dan mengembangkan teknologi. Prinsip ini dimaksudkan untuk merangsang pertumbuhan ekonomi Indonesia dala arti meningkatkan taraf hidup dan kualitas kehidupan rakyat Indonesia.

Dari segi bahasa, perlisensian berakar dari kata dasar lisensi. Kata tersebut berasal dari bahasa asing license yang dalam bahasa Indonesia berarti surat ijin. Pengertian yang terkandung di dalamnya berpangkal semuanya pada ijin tadi, walaupun penggunaannya dapat berbeda tergantung dari tujuan dan sumber yang memberi ijin. White ${ }^{11}$ menyajikan pengertian : $A$ license is the granting permission of rights to make, use / or sell a certain product, design, or process or to perform certain other actions, the granting being done by a party who has the rights to do so.

Berdasarkan pengertian di atas dapat diketahui unsur lisensi, yaitu pemberian ijin kepada orang atau badan hukum, diberikan pihak yang memiliki kewenangan atau hak, untuk melakukan sesuatu yang tertentu dengan hak tersebut, dan penggunaannya terikat pada syarat tertentu. Ijin penggunaan hak itulah yang menjadi ciri pokok, dan membedakan lisensi dari berbagai bentuk dan jenis hubungan lainnya. Dengan pengertian tadi, perlisensian berarti ikhwal dan kegiatan pemberian dan perolehan lisensi.

Dalam sistem hukum sipil (civil law system), lisensi sebagai suatu bentuk perjanjian pada dasarnya tidak dikenal. $^{12}$ KUH Perdata tidak mengenal

11 Edward P White, 1990, Licencing :A Strategy for Profits, KEW Licensing, Chaper Hill, NC, hlm. 5.

12 Badan Pembinaan Hukum Nasional, 2006, Laporan Akhir tentang Kompilasi Bidang Hukum Perjanjian 
lisensi ke dalam bentuk perjanjian, dikarenakan lisensi adalah lembaga hukum asing yang berasal dari sistem hukum lain yang masuk ke dalam sistem tata hukum Indonesia.

Baru dalam perkembangan akhirakhir ini sesuai dengan perkembangan masyarakat, lisensi sebagai bentuk perjanjian dikenal diluar dari yang ada dalam Kitab Undang-undang Hukum Perdata. Sebagai suatu bentuk perjanjian, lisensi masuk ke dalam sistem tata hukum Indonesia melalui 2 (dua) macam cara yakni (a). melalui proses legislatif atau melalui proses pembentukan undang-undang oleh DPR dan (b). melalui yurisprudensi ataupun melalui praktik.

Seperti halnya perjanjian pada umumnya, perlisensian juga merupakan peristiwa hukum. Persetujuan pemberian lisensi dan dengan demikian merupakan penerima lisensi, dengan segala hak dan kewajiban yang disepakati keduanya, adalah peristiwa hukum. Perlisensian karenanya adalah perjanjian, dan terhadapnya berlaku pula ketentuan hukum perjanjian. Dalam literatur lain mengatakan bahwa perjanjian lisensi adalah perjanjian antara dua pihak atau lebih, yang mana salah satu pihak yaitu pemegang hak bertindak sebagai pihak yang memberikan lisensi, sedangkan pihak yang lain bertindak sebagai pihak yang menerima lisensi. Pengertian lisensi itu sendiri adalah izin untuk menikmati manfaat ekonomi dari suatu objek yang dilindungi HKI untuk jangka waktu tertentu. $^{13}$

Perjanjian lisensi harus secara tertulis dan harus ditandatangani oleh kedua pihak. Perjanjian lisensi sekurangkurangnya memuat informasi tentang :

1) Tanggal, bulan dan tahun tempat dibuatnya perjanjian lisensi;

Lisensi, BPHN, Jakarta, hlm.10.

13 Andi Fahmi Lubis, dkk, 2009, Hukum Persaingan Usaha Antara Teks \& Konteks, Penerbit GTZ GmbH, Jerman, hlm. 239
2) Nama dan alamat lengkap serta tandatangan para pihak yang mengadakan perjanjian lisensi;

3) Objek perjanjian lisensi;

4) Jangka waktu perjanjian lisensi;

5) Dapat atau tidaknya jangka waktu diperpanjang;

6) Pelaksanaan lisensi untuk seluruh atau sebagian dari hak eksklusif;

7) Jumlah royalti dan pembayarannya;

8) Dapat atau tidaknya penerima lisensi memberikan lisensi lebih lanjut kepada pihak ketiga;

9) Batas wilayah berlakunya perjanjian lisensi, apabila diperjanjikan;

10) dan

11) Dapat atau tidaknya pemberi lisensi melaksanakan sendiri karya yang telah dilisensikan.

Sesuai dengan ketentuan dalam paket Undang-Undang tentang HKI, maka suatu perjanjian lisensi wajib dicatatkan pada Direktorat Jenderal Hak Kekayaan Intelektual yang kemudian dimuat dalam Daftar Umum dengan membayar biaya yang besarnya ditetapkan dengan Keputusan Menteri. Namun, jika perjanjian lisensi tidak dicatatkan, maka perjanjian lisensi tidak mempunyai akibat hukum terhadap pihak ketiga.

Menurut Suyud Margono, ${ }^{14}$ lisensi dapat dilakukan secara eksklusif (dimana lisensor tidak memberikan kepada siapapun sebuah lisensinya yang meliputi seluruh ruang lingkup kegiatan), sendiri (sama dengan lisensi eksklusifnya, tetapi lisensor dapat mencadangkan kepada kemungkinan untuk mengeksploitasi hakhak) atau non-ekskusif (dimana lisensor menahan hak-hak tersebut untuk kemudian diberikan lisensi pada obyek yang sama ataupun area lain dalam lisensi.

Secara keseluruhan, lisensi eksklusif (exclusive licensee) dari hak kekayaan intelektual seperti hak paten, desain industry dan hak cipta yang diatur dalam

\footnotetext{
${ }^{14}$ Suyud Margono, Op. Cit, hal.41
} 
uandang-undang mensyaratkan segi formalitas tertentu sebagaimana diuraikan di atas, tetapi dalam hal ketentuan mengenai kontraktual yang secara detail diatur seharusnya mengenai kejelasan dengan standar yang tinggi (high standard of clarity) serta kepastian dalam menyebutkan hak dan kewajiban para pihak. ${ }^{15}$

\section{Joint Venture}

Kemajuan teknologi informasi dan transportasi yang sangat pesat juga telah mendorong globalisasi Hak Kekayaan Intelektual (HKI). Barang atau jasa yang hari ini diproduksi oleh suatu negara, di saat berikutnya telah dapat dihadirkan di negara lain. Kehadiran barang atau jasa yang selama proses produksinya telah menggunakan HKI, dengan demikian juga memerlukan perlindungan $\mathrm{HKI}$ atas barang yang bersangkutan. Kebutuhan untuk melindungi barang atau jasa dari kemungkinan pemalsuan atau persaingan yang tidak wajar (curang) juga berarti kebutuhan untuk melindungi HKI yang digunakan pada proses pembuatan produk yang bersangkutan. ${ }^{16}$

Perlindungan Hak Kekayaan Intelektual menjadi penting oleh karena adanya persetujuan Trade Related Aspects of Intellectual Property Rights (TRIPs) yang merupakan salah satu dokumen penting yang dihasilkan dalam Putaran Akhir Uruguay (The Uruguay Final Round) dalam rangka pendirian World Trade Organization (WTO). TRIPs bertujuan untuk melindungi dan menegakkan hukum Hak Kekayaan Intelektual (HKI) guna mendorong timbulnya inovasi, pengalihan serta penyebaran ilmu pengetahuan, teknologi, seni dan sastra, sehingga bermuara pada kesejahteraan sosial ekonomi

15 Ibid

16 Suyud Margono dan Amir Aksa, Komersialisasi Aset Intelektual, Gramedia Widiasarana Indonesia, Jakarta, 2002, hal. 2-3
Masyarakat.

Pertumbuhan ekonomi suatu negara berkembang, termasuk Indonesia, sangat bergantung pada modal asing, dan sistem HKI memegang peranan penting dalam menarik adanya investor asing untuk menanamkan modalnya di Indonesia. Peranannya adalah dengan menciptakan iklim yang kondusif dan aman bagi kegiatan eksploitasi dan komersialisasi HKI asing, termasuk memberikan perlindungan yang memadai terhadap paten, merek terkenal, desain industri, rahasia dagang, hak cipta dan HKI lainnya yang dimiliki oleh investor asing tersebut.

Pengembangan HKI terwujud dalam kebutuhan akan perlindungan hukum yang bertumpu pada pengakuan terhadap hak kekayaan intelektual dan hak untuk atau dalam waktu tertentu mengeksploitasi komersialisasi atau menikmati sendiri kekayaan tersebut. Selama kurun waktu tertentu orang lain hanya dapat menikmati atau menggunakan atau mengeksploitasi hak tersebut atas izin pemilik hak. Karena itu, perlindungan dan pengakuan hak tersebut hanya diberikan khusus kepada orang yang memiliki kekayaan tadi sehingga sering dikatakan bahwa hak seperti itu eksklusif sifatnya.

Joint Venture adalah cara yang ketiga yang dapat dilakukan oleh pemilik kekayaan intelektual dalam melindungi haknya ketika dilakukan pengeksploitasian dan komersialisasi. Joint venture dapat dilakukan antara pemilik kekayaan intelektual dalam hal ini industry kecil menengah dan investor baik investor nasional maupun investor asing. Sementara joint venture dalam pengertian yang luas joint venture atau perjanjian patungan adalah bentuk persekutuan yang menekankan kerjasama lebih daripada untuk suatu yang sementara sifatnya. Perusahaan patungan terbentuk ketika dua pihak atau lebih, baik secara pribadi maupun perusahaan bermaksud menjadi 
patner satu sama lainnya untuk suatu kegiatan dan mengatur secara bersama suatu perusahaan baru yang sahamsahamnya dimiliki secara bersama pula. ${ }^{17}$

Menurut Ian Hewitt, ${ }^{18}$ joint venture dapat mencakup tiga hal, yaitu : pertama, contractual joint venture; merupakan kerjasama dua atau lebih para pihak dalam rangka menjalankan suatu bisnis atau proyek tertentu. kedua, partnership merupakan bentuk kerjasama yang sederhana dengan tidak mendirikan sebuah perusahaan. Ketiga, corporate joint venture, merupakan kerjasama yang dilakukan dengan mendirikan sebuah perusahaan dengan menggabungkan berbagai potensi dan permodalan yang dimiliki.

Sedangkan menurut Pedoman Perundingan Pembentukan Joint Venture yang dikeluarkan United Nation Industrial Organization, terdapat dua bentuk usaha patungan (joint venture) yakni contractual joint venture dan equity joint venture. Dalam contractual joint venture, kerjasama dilakukan atas dasar perjanjian antara pihak asing dengan pemerintah Negara penerima modal dalam hal penyediaan modal, peralatan, hak hak milik industrian, bantuan teknik dan keterampilan. Pemilikan perusahaan di tangan pemerintah. Pihak asing memperoleh imbalan royalty yang harus dibayar berdasarkan hasil produksi, penjualan dan keuntungan perusahaan. Adapun equity joint venture merupakan bentuk usaha patungan yang umum terjadi dalam rangka penanaman modal asing di Negara-negara berkembang. Dalam usaha patungan semacam ini, para pihak memiliki usaha secara bersama-sama melalui penggabungan modal berdasarkan

17 Erman Rajagukguk, Indonesiasisasi Saham, Cet.II, Jakarta, Rineka Cipta, 1994, hal. 12

${ }^{18}$ Ian Hewitt, Joint Ventures, Second Edition, (Sweet and Maxswell a Thomson Company), 2001, hal. 59 perbandingan modal yang ditanam atau diinvestasikan. Kerjasama atas penggabungan modal ini dapat dilakukan melalui usaha perusahaan yang sudah ada, tetapi pada umumnya para mitra cenderung untuk mendirikan perusahaan baru melalui pembentukan joint venture campany. ${ }^{19}$

Senada dengan pendapat di atas, Suyud Margono $^{20}$ menyatakan bahwa joint venture adalah bentuk kerjasama antara suatu perusahaan ataupun perorangan dapat dibuat dalam bentuk sebuah asosiasi antara dua atau lebih perusahaan dengan mengcombine bentuk pengembangan dan inovasi, marketing ataupun finansial skills. Banyak joint venture dilakukan untuk mengekploitasi kesempatan pada pasar yang spesifik, persyaratannya, dilakukan untuk mencapai tujuan tertentu. bentuk kontraktual (contractual joint venture) dapat menjadi pilihan dan melalui sebuah kontrak akan mendefinisikan secara alamiah kontribusi dari setiap pihak dalam melaksanakan persetujuan (dalam kontrak) yang mana menjadi hal yang bersifat umum.

Jika hak kekayaan intelektual sedang di eksploitasi di Negara lain mungkin terdapat restriksi daripada pemilikan perusahaan-perusahaan asing, maka pilihan dari kontraktual joint venture akan memperbolehkan ahli untuk mensupply dari perusahaan-perusahaan asing kepada sebuah perusahaan konversional. ${ }^{21}$

Kadang sebuah asosiasi kontrak bisnis dapat didahulukan ke dalam bentuk sebuah badan hukum baru, hal ini terpisah dari bentuk lain. Hal ini menjadi kebiasaan dalam praktek untuk menjalankan

${ }^{19}$ Lihat Manual on the Establishment on Industrial joint Venture Agreement in Developing Caountries, (UN-1991) dalam Ridwan Khairandy, Kompetensi Absolut Dalam Penyelesaian Sengketa di Perusahaan Joint Venture, Jurnal Hukum Vol 26 No. 24, 2007, hal. 43

${ }^{20}$ Suyud Margono, Op.Cit, hal. 43

$21 \mathrm{~T}$ Harper dalam Suyud Margono, ibid.hal.43 
perusahaan patungan antara perusahaan domestik dengan suatu perusahaan asing suatu Negara. Membentuk sebuah perusahaan baru disamping tetap menjalankan sebuah pengaturan kontraktual yang dijalankan dalam bentuk long-term project dan fungsi kerjasama juga tetap diwujudkan. Jika keseluruhan kepemilikan dari korporasi asing terhalangi beroperasinya di Negara-negara tertentu, selanjutnya equity joint venture akan bekerjasama dengan peserta lokal dan pemilik hak akan mensyaratkannya. Kebanyakan dari pertimbangan yang relevan dengan sebuah lisensi dapat juga diterapkan dalam joint venture agreements. ${ }^{22}$

Di Indonesia, perjanjian Joint venture atau patungan mengenai penanaman modal asing tidak saja tunduk kepada Kitab Undang-Undang Hukum Perdata, khususnya Buku III, Bab 2 tentang Perikatan-perikatan yang dilahirkan dari kontrak atau persetujuan, tetapi juga ketentuan-ketentuan yang dikeluarkan pemerintah sehubungan dengan penanaman modal. Terdapat 4 (empat) persyaratan utama yang harus dipenuhi agar suatu kontrak atau perjanjian mengikat para pihak; (1) sepakat mereka yang mengikatkan dirinya; (2) kecakapan untuk membuat suatu perikatan; (3) Perikatan harus mengenai sesuatu hal tertentu; (4) Perikatan harus mengenai suatu yang tidak bertentangan dengan hukum. ${ }^{23}$

Perikatan yang memenuhi persyaratan tersebut di atas secara hukum mengikat para pihak. Ia tidak akan berakhir atau diakhiri tanpa persetujuan para pihak atau karena alasan-alasan yang oleh undang-undang dinyatakan cukup untuk membatalkan persetujuan tersebut. Selanjutnya perikatan tersebut harus dilaksanakan dengan itikad baik. Sebagai perbandingan, di Amerika Serikat umpamanya, menurut keputusan-keputusan pengadilan, aspek yang penting dari perjanjian joint venture adalah bahwa ketentuan-ketentuan

kontraktual sebagaimana yang diterapkan kepada kontrak-kontrak yang sederhana berlaku juga terhadap kontrak joint venture. Dengan demikian hubungan-hubungan antara para patner dalam joint venture tergantung kepada kehendak yang sebenarnya dari mereka, yang akan ditetapkan sesuai ketentuan-ketentuan sebenarnya mengenai penafsiran suatu kontrak. ${ }^{24}$

\section{Franchising (Waralaba).}

Format atau model bisnis waralaba merupakan format bisnis yang telah terbukti mampu meningkatkan akselerasi perkembangan perekonomian dan merupakan sistem yang tepat bagi terciptanya pemerataan kesempatan berusaha. Umumnya format bisnis waralaba berkembang di sektor yang padat karya dan dapat dilakukan oleh industry kecil menengah sehingga sangat cocok dikembangkan di Indonesia pada umumnya dan di Pulau Lombok pada khususnya. Agar waralaba dapat berkembang dengan pesat, maka persyaratan utama yang harus dimiliki suatu teritori adalah kepastian hukum yang mengikat baik franchisor maupun franchisee, karenanya kalau diperhatikan bahwa di Negara-negara yang memiliki kepastian hukum yang jelas, bisnis dengan format waralaba ini berkembang dengan pesat seperti di Amerika Serikat, Australia dan Jepang.

Di Indonesia masalah berusaha dengan format atau model waralaba, pada awalnya ada sebagian masyarakat yang skeptis, hal ini disebabkan karena masih lemahnya masalah kepastian hukumnya, namun kalau dilihat dan diperhatikan dari waktu ke waktu saat ini kepastian hukum berusaha dengan format bisnis waralaba

\footnotetext{
${ }^{22}$ J Kenny dalam Suyud Margono, Ibid

${ }^{23}$ Erman Rajagukguk, Op. Cit, hal.13
} 
jauh lebih baik dari tahun sebelum tahun 1997. Tonggak kepastian hukum akan format bisnis waralaba ini dimulai pada tanggal 18 Juni 1997 yaitu dengan dikeluarkannya Peraturan Pemerintah Republik Indonesia Nomor 16 tahun 1997 tentang Waralaba.

Selanjutnya ketentuan-ketentuan lain yang mendukung kepastian hukum dalam format bisnis waralaba adalah dengan dikeluarkannya Keputusan Menteri Perindustrian dan Perdagangan RI No.259/MPP/KEP/7/1997 tanggal 30 Juli 1997 tentang Ketentuan Tata Cara Pelaksanaan Pendaftaran Usaha Waralaba. Demikian juga di dalam Undang-Undang Tentang Hak Kekayaan Intelektual seperti Undang-Undang Merek, Undang Undang Rahasia Dagang, Undang-Undang Paten, Undang-Undang Desain Industri memberikan penguatan-penguatan kepastian hukum terhadap bisnis waralaba yang memanfaatkan hasil-hasil Kekayaan Intelektual seseorang atau suatu badan hukum.

Dengan Demikian, maka menurut D Gurnick, ${ }^{25}$ franchising adalah model yang paling disukai businessman karena modelnya yang efektif dalam menyuply sebuah atau sebagai model, atau jasa kepada pasar melalui model franchising. Franchising adalah bentuk penyuplaian produk atau jasa kepada pasar, dimana dalam pengaturan bisnis secara khusus dilakukan oleh franchisee (penerima franchise) dan franchisor (pemberi franchise). Bagaimanapun juga franchise adalah wujud pembelian hak untuk mengkopi kekayaan intelektual lain dalam atau terhadap niat bisnis, merek dagang, produk atau informasi rahasia. Disamping itu franchisor juga menyediakan support dalam bentuk training, ketentuan strategi marketing, group periklanan dan kemungkinan pengaturan untuk perchaisingnya.

25 D Gurnick dalam Suyud Margono, $O p$. Cit, hal. 44
Di Indonesia pengaturan tentang perjanjian franchising atau waralaba mengacu kepada hukum perjanjian yang harus mengikuti persyaratan perjanjian sebagaimana yang diataur dalam Kitab Undang-Undang Hukum Perdata atau Burgerlijk Wetbook (BW) yang selanjutnya ketentuan dalam penyusunan perjanjian franchising tidak boleh bertentangan dengan peraturan perundangUndangan yang berlaku lainnya seperti Undang-Undang bidang perusahaan, KUHD, UU Perseroan Terbatas, UndangUndang dalam bidang Hak Kekayaan Intelektual (HKI) seperti UU Merek, Paten, Desain Industri, Rahasia Dagang, Desain Tata Letak Sirkuit Terpadu, Varitas Tanaman dan berbagai peraturan perundang-undangan lainnya.

Dalam hukum perjanjian, perjanjian waralaba merupakan perjanjian khusus karena tidak dijumpai dalam Kitab Undang- undang Hukum Perdata. Perjanjian ini dapat diterima dalam hukum karena didalam Kitab Undang-Undang Hukum Perdata ditemui satu pasal yang mengatakan adanya kebebasan berkontrak. Pasal itu mengatakan bahwa perjanjian yang dibuat secara sah berlaku sebagai undangundang bagi mereka yang membuatnya (Pasal 1338 Kitab Undang-undang Hukum Perdata). ${ }^{26}$

Perjanjian dibuat secara sah artinya bahwa perjanjian itu telah memenuhi syarat-syarat yang ditentukan dalam undang- undang. Artinya perjanjian itu tidak bertentangan dengan Agama dan ketertiban umum, dan tidak bertentangan dengan kesusilaan, dan undang- undang itu sendiri. Perjanjian waralaba dapat dikatakan suatu perjanjian yang tidak bertentangan dengan undang-undang, agama ketertiban umum dan kesusilaan, karena

26 Wan Sadjaruddin Baros, Aspek Hukum Waralaba, Digitized by USU Digital Library, 2003, hal.2 
itu perjanjian waralaba itu sah, dan oleh karena itu perjanjian itu menjadi undangundang bagi mereka yang membuatnya, dan mengikat kedua belah pihak.

Pada dasarnya waralaba berkenan dengan pemberian izin oleh seorang pemilik waralaba (franchisor) kepada orang lain atau beberapa orang untuk menggunakan sistem atau cara pengoperasian suatu bisnis. Pemberian izin ini meliputi untuk menggunakan hak-hak pemilik waralaba yang berada dibidang hak milik intelektual (intelectual property rights). Pemberian izin ini kadangkala disebut dengan pemberian izin lisensi.

Perjanjian lisensi biasa tidak sama dengan pemberian (perjanjian) lisensi waralaba. Kalau pada pemberian (perjanjian) lisensi biasanya hanya meliputi pemberian izin lisensi bagi penggunaan merek tertentu. Sedangkan pada waralaba, pemberian izin lisensi meliputi pelbagai macam hak milik intelektual, Keseluruhan hak-hak milik intelektual bahwa alat- alat dibeli atau disewakan darinya. Selain yang disebut diatas perjanjian waralaba (franchising): Pemberian lisensi hukum tentang nama perniagaan, merek, model, desain dan sebagainya. Bidang-bidang hukum itu dapat dikelompokkan dalam bidang hukum perjanjian dan dalam bidang hukum tentang hak milik intelektual. ${ }^{27}$

Dalam hukum perjanjian, setiap perjanjian apapun namanya baik perjanjian yang bernama atau yang diatur dalam Kitab Undang-Undang Hukum Perdata maupun perjanjian yang tidak bernama atau tidak diatur dalam Kitab UndangUndang Hukum Perdata harus memenuhi syarat-syarat yang ditentukan oleh Kitab Undang-Undang Hukum Perdata (KUH Perdata). Agar supaya perjanjian yang dibuat oleh para pihak menjadi sah harus dipenuhmya syarat - syarat yang ditentukan dalam Pasal 1320 KUH Perdata yaitu:

a. Adanya kesepakatan dari para pihak yang membuat perjanjian. Artinya untuk membuat perjanjian tidak boleh ada paksaan, tidak boleh ada penipuan, dan tidak boleh ada kekhilafan. Kalau ada perjanjian dibuat dengan tidak sepakat maka perjanjian itu dapat dimintakan pembatalannya.

b. Para pihak harus cakap (wenang) bertmdak dalam hukum Artinya pihak-pihak yang membuat perjanjian tersebut harus cakap (wenang) untuk membuat perjanjian. Maksudnya orang yang cakap (wenang) adalah orang yang sudah dewasa, orang yang tidak berada dibawah pengampuan (curatele) seperti orang yang sakit otak, mata gelap, pemabuk, penjudi, dan sebagainya.

c. Sesuatu hal tertentu. Artinya yang menjadi objek perjanjian tersebut, misalnya perjanjian waralaba jenis apa, makanankah, restorankah dan sebagainya, Kalau hal ini tidak dapat ditentukan maka perjanjian tersebut batal demi hukum, artinya perjanjian itu tak sah.

d. Sebab yang halal. Artinya perjanjian itu dibuat tidak bertentangan dengan undang-undang, agama, ketertiban umum, dan kesusilaan. Kalau ini tak halal, artinya bertentangan dengan undang-undang, agama, ketertiban umum dan kesusilaan, maka perjanjian yang dibuat itu tidak sah. Keempat syarat inilah yang harus dipenuhi. Apabila sudah dipenuhi, barulah perjanjian itu disebut perjanjian yang sah. Apabila perjanjian dibuat secara sah maka berlakuklah ia sebagai undangundang bagi pihak yang membuatnya (Pasal 1338 KUH Perdata).

Demikian juga dalam pembuatan 
perjanjian franchise atau waralaba, maka harus juga menenuhi ketentuan KUH Perdata yaitu Pasal 1320 yang secara singkat dapat diuraikan yaitu harus ada kesepakatan antara pemberi dan penerima franchaise, para pihak yang membuat perjanjian franchaise tersebut sudah cakap atau memenuhi ketentuan kedewasaan sebagaimana ditentukan undang-undang, obyek yang diperjanjikan dalam perjanjian waralaba ini tertentu sifatnya seperti apakah obyeknya penggunaan merek dagang atau merek jasa atau penjualan produk dan lain sebagianya, kemudian harus mencerminkan sebab yang halal artinya perjanjian waralaba yang dibuat tidak boleh bertentangan dengan Undangundang lainnya yang berlaku di Indonesia, kesusilaan, ketertiban umum dan salah satu pihak tidak di bawah tekanan dari pihak lainnya, artinya mereka para pihak yang membuat perjanjian waralaba tersebut berada dalam kondisi bebas untuk menentukan kehendaknya.

\section{PENUTUP}

1. Fungsi Hukum Hak Kekayaan Intelektual Terhadap Invensi yang dihasilkan oleh Industri dan Usaha Kecil Menengah adalah untuk memberikan kepastian hukum melalui proses pendaftaran (prinsif konstitutif), karena setiap invensi dan kreasi yang dihasilkan oleh Industri Kecil Menengah baik merek, desain industry, paten, desain tata letak sirkuit terpadu dan varitas tanaman baru sesuai dengan paket hukum atau undang-undang bidang Hak Kekayaan Intelektual sebagaimana tersebut di atas, maka wajib didaftarkan terlebih dahulu baru kemudian akan mendapatkan perlindungan hukum, kecuali Hak Cipta dan Radasia Dagang karena menganut prinsif deklaratif yaitu tanpa ada kewajiban untuk melakukan pendaftaran artinya pemilik atau penemu suatu ciptaan atau pemilik rahasia dagang tetap akan dilindungi oleh hukum kekayaan intelektual apabila suatu ciptaan sudah diwujudkan dalam bentuk karya yang nyata dan sudah diumumkan oleh pencipta baik dengan cara diperdegarkan, dipentaskan, dinyanyikan, begitu pula dengan rahasia dagang apabila suatu informasi itu dirahasiakan dan dijaga rasia itu oleh pemiliknya maka sejak saat dirahasiakan dan dijaga rahasia informasi tersebut akan dilindungi oleh hukum serta tidak ada kewajiban hukum untuk mendaftarkan terlebih dahulu.

2. Mekanisme perlindungan hukum dalam kegiatan eksploitasi dan komersialisasi kekayaan intelektual oleh Industri dan Usaha Kecil Menengah adalah dapat dilakukan melalui beberapa mekanisme yaitu melalui jual beli lepas atau pengalihan hak, melalui lisensi atau pemanfaatan hak, melalui joint venture atau usaha patungan, dan melalui franchising atau usaha waralaba. Empat mekanisme ini dapat dilakukan oleh Industri Kecil Menengah sebagai pemilik kekayaan intelektual untuk agar mendapat kepastian dan perlindungan hukum baik bagi pemilik maupun bagi penerima hak dalam pemanfaatan kekayaan intelektual ketika melakukan komersialisasi dan eksploitasi.

\section{DAFTAR PUSTAKA}

Bambang Waluyo, Penelitian Hukum dalam Praktek, Sinar Grafika, Jakarta, 1996

I Made Sukadana, Mediasi Peradilan Mediasi Dalam Sistem Peradilan Perdata Indonesia Dalam Rangka Mewujudkan Proses Peradilan yang Sederhana, Cepat, dan Biaya Ringan, Mediasi Peradilan, Jakarta, 2012. 
Ibrahim Johni, Teori dan Metode Penelitian Hukum Normatif, Bayu Media Publishing, Malang, 2005.

Lexy J. Moleong, Metodologi Penelitian Kualitatif, Remaja Rosdakarya, Bandung, 1993

Peter Mahmud Marzuki, "Batas-Batas Kebebesan Berkontrak" Yudika, Vol. 18 Nomor 3 Mei 2003. dalam Yohanes Sogar Simamora, "Hukum Perjanjian, Prinsip Kontrak Pengadaan Barang Dan Jasa Oleh Pemerintah" Cetakan Pertama Penerbit Laksbang Pressindo. Yokyakarta. 2009

Ridwan Khairandy, 2006, Pengantar Hukum Dagang, UII Press, Yogyakarta,

Salim HS, "Hukum Kontrak Teori Dan Teknik Penyusunan Kontrak" Cetakan keempat. Penerbit Sinar Grafika. Jakarta. 2006.

Salim, HS, dkk. "Perancangan Kontrak Dan Memorandum Of Undestanding”, Sinar Grafika. Jakarta. 2007.

Salim, HS. "Pengantar Hukum Perdata Tertulis (BW)”, Cetakan kelima. SinarGrafika. Jakarta.

Soerjono Soekanto dan Sri Mulyadi, Penelitian Hukum Normatif, Suatu Tujuan Singkat, Raja Grafindo Persada, Jakarta, 1995.

Subekti, "Hukum Perjanjian”, Penerbit Intermesa. Jakarta. 2002

Sudikno Mertokusumo, "Mengenal Hukum”. Penerbit Liberty. Yokyakarta. 1986

Sunaryati Hartono, Penelitian Hukum di Indonesia pada Akhir Abad ke-20, Alumni, Bandung, 1994.

Adiwilga, Rizka, Pendayagunaan Desain Produk Industri dan Rahasia Dagang Bagi Pengembangan Industri Kerajinan Rakyat di DIY, Makalah Seminar Nasional "Implementasi UU Desain Industri, Rahasia Dagang, DTLST, Yogyakarta, 4 Oktober 2000

Djumhana, Muhammad, Aspek-aspek Hukum Desain Industri di Indonesia, Citra Aditya Bandung, 1999
Djumhana, Muhammad dan E. Djubaedillah, Hak Kekayaan Intelektual (Sejarah, Teori dan Prakteknya di Indonesia), Citra Aditya Bakti Bandung, 2003

Muhammad, Abdulkadir, Kajian Hukum Ekonomi Hak Kekayaan Intelektual, Citra Aditya Bakti Bandung, 2001

Margono, Suyud, Hak Kekayaan Intelektual Komentas Atas Undangundang Rahasia Dagang, Desain Industri, Desain Tata Letak Sirkuit Terpadu, Novinda Pustaka Mandiri, Jakarta, 2001

Mayana, Ranti Fauza, Perlindungan Desain Industri di Indonesia dalam Era Perdagangan Bebas, Grasindo, Jakarta, 2004

Prosiding, Rangkaian Lokakarya Terbatas Masalah-masalah Kepailitan dan Wawasan Hukum Bisnis Lainnya, Hak Kekayaan Intelektual dan Perkembangannya, 2004

Rahardjo, Satcipto, Ilmu Hukum, Bandung, Citra Aditya Bakti, 1996

Sardjono, Agus, Pengetahuan Tradisional; Studi Mengenai Perlindungan Hak Kekayaan Intelektual Atas Obat-obatan, Disertasi, Universitas Indonesia, Jakarta, 2004

Santosa, Budi, Butir-butir Berserakan tentang Hak Kekayaan Intelektual (Desain Industri), Mandar Maju, Bandung, 2005

Sembiring, Sentosa, Hak Kekayaan Intelektual Dalam Berbagai Peraturan Perundang-undangan, Irama Widya, Bandung, 2006

Sutrisno, Nandang, Perlindungan Hukum Terhadap Desain Industri, Rahasia Dagang, DTLST, Makalah Seminar, Yogyakarta, 4 Oktober 2000

Simanjuntak, Yoan Nursari, Hak Desain Industri Sebuah Realitas Hukum dan Sosial, Srikandi, Surabaya, 2006

Usman, Rachmadi, Hukum Hak Atas Kekayaan Intelektual, Perlindungan dan 
Dimensi Hukumnya di Indonesia, Alumni, Bandung, 2002

Zem, Umar Purba, Achmad, Hak Kekayaan Intelektual Pasca TRIPs, Alumni, Bandung, 2005

\section{Undang-Undang :}

Undang-Undang Nomor 20 Tahun 2008 Tentang Usaha Mikro, Kecil dan Menengah

Undang-Undang Nomor 28 tahun 2014 Tentang Hak Cipta

Undang-Undang Nomor 13 tahun 2016

Tentang Paten
Undang-Undang Nomor 20 tahun 2016 Tentang Merek dan Indikasi Geografis

Undang-Undang Nomor 30 tahun 2000 Tentang Rahasia Dagang

Undang-Undang Nomor 31 Tahun 2000 Tentang Desain Industri

Undang-Undang Nomor 32 tahun 2000 Tentang Desain Tata Letak Sirkuit Terpadu

Undang-Undang Nomor 29 Tahun 2000 Tentang Perlindungan Varitas Tanaman Baru 